\title{
Stress-Tolerant Cassava: The Role of Integrative Ecophysiology-Breeding Research in Crop Improvement
}

\author{
Mabrouk A. El-Sharkawy \\ Centro Internacional de Agricultura Tropical (CIAT), Cali, Colombia. \\ Email: mabrouk99@hotmail.com, elsharkawy@emcali.net.co
}

Received March 20 $0^{\text {th }}, 2012$; revised April 18 ${ }^{\text {th }}, 2012$; accepted May $2^{\text {nd }}, 2012$

\begin{abstract}
This review highlights an integrative multidisciplinary eco-physiological, breeding and agronomical research on the tropical starchy root crop cassava conducted at CIAT. Laboratory and field studies have elucidated several physiological/biochemical mechanisms and plant traits underlying the high productivity in favorable conditions and tolerance to stressful environments, such as prolonged water stress and marginal low-fertility soils. Cassava is endowed with inherent high photosynthetic capacity expressed in near optimal environments that correlates with biological productivity across environments and wide range of germplasm.Field-measured photosynthetic rates were also associated with root yield, particularly under prolonged drought. Extensive rooting systems and stomatal sensitivity to both atmospheric humidity and soil water shortages underlie tolerance to drought. The $\mathrm{C}_{4}$ phosphoenolpyruvate carboxylase (PEPC) was associated with photosynthesis and yield making it a selectable trait, along with leaf duration, particularly for stressful environments. Germplasm from the core collection was screened for tolerance to soils low in P and K, resulting in the identification of several accessions with good levels of tolerance. Cassava has a comparative advantage against major tropical food and energy crops in terms of biological productivity. Results also point to the importance of field research versus greenhouse or growth-chamber studies. In globally warming climate,the crop is predicted to play more role in tropical and subtropical agro-ecosystems. More research is needed under tropical field conditions to understand the interactive responses to elevated carbon dioxide, temperature, soil fertility, and plant water relations.
\end{abstract}

Keywords: Abiotic Stress; Agriculture; Breeding; Climate Change; Cultivars; Drought; Ecophysiology; Food Security; Modeling; Nutrients; Photosynthesis; Productivity; Semiarid; Soils; Storage Roots; Water Stress; Yield

\section{Introduction}

Despite its domestication thousands of years ago by natives of the New World, until the early $20^{\text {th }}$ century cassava was a neglected and less known crop outside the tropical and subtropical belt of Africa, Asia and Latin America, where it is commonly cultivated. However, during the colonial period, mainly in East and South Africa, the plant drew the attentions of the European colonists, and hence was generally researched for its importance as anti-famine food security source by subsistence farming systems. In the following subsections, we highlight the history and the important features of this highly productive and resilient crop, which lately have received greater attentions and interests from many international research and development organizations [1].

\subsection{The Origin, Domestication and Distribution of the Plant}

The word cassava is derived from "casabi", the local name given by the Arawaks Amerindians to the starchy roots. It is also known as "yuca" in Spanish, "manioc" in French, "mandioc" in Portuguese;" cassave" in Dutch and "maniok" in German [1]. Cassava plant (Manihot esculenta Crantz, Euphorbiaceae) is a perennial shrub of the New World. It is an outbreeding species possessing $2 \mathrm{n}=36$ chromosomes, and is considered to be an amphidiploid or sequential allopolyploids. The plant was believed to be domesticated before $4000 \mathrm{BC}$ in its Amazonian original habitat, and in west Coast of Peru, as well as in Mesoamerica [2,3]. It became widely cultivated as a staple crop in pre-Columbian tropical America. Also, it was suggested that the wild species, Manihot flabellifolia Pohl, is the likely progenitor of modern commercial cultivars and of landraces of cassava that are no longer considered cultigens (i.e. M. esculenta Crantz subspecies esculenta, as proposed by [2]). After the conquest of the Americas, European traders, especially the Portuguese, soon recognized its importance and, in the $16^{\text {th }}$ century, introduced it into Africa, and later to Asia. Nowadays, cassava is cultivated in most tropical countries situated in the equatorial belt, between $30^{\circ}$ north and $30^{\circ}$ south of 
the equator, and from sea level to elevations of 2000 meters under annual precipitation ranging from $500 \mathrm{~mm}$ (in semiarid eco-zones) to $>2000 \mathrm{~mm}$ (humid eco-zones), which indicates its adaptability to a wide range of environments and ecosystems.

\subsection{The Importance, Production Systems and Use of the Crop}

The crop is widely grown as an annual staple food and animal feed by resource-poor smallholders mostly on marginal infertile soils without purchased production inputs in countries of tropical and sub-tropical Africa, Asia and Latin America, with a total cultivated area $>20$ million hectares producing over 240 million tons of fresh storage roots, more than $70 \%$ of it being in Africa and Asia, with the greatest share in the former [4,5]. Nigeria is the largest world producer of cassava (with $>40$ million tons annually). It is currently the world's fourth most important staple and carbohydrate-enrichedfood (about $85 \%$ starch content on dry weight basis of peeled storage roots) after rice, wheat and maize and is an important component in the diet of over 800 million people across continents. In the tropical and sub-tropical countries, where cassava is produced, total human calories intake from cassava products exceeds 200 billion kcal/day [6]. Because cassava roots are very low in protein content (values range among cultivars from 5 to $19 \mathrm{~g} / \mathrm{kg}$ dry matter, based on an average conservative Kjeldahl nitrogento-protein conversion factor of 2.49 - 3.67 [7]), human requirement for protein and other essential nutrients are commonly fulfilled by other food sources. Cassava leaves are also consumed and constitute an excellent source for protein supplement (leaf crude protein contents on a dry basis range among cultivars from $21 \%$ to $39 \%$; [8]), minerals and vitamins for the human diet in many African and Asian countries, as well as in certain regions of Brazil [9-11]. Nevertheless, cassava roots and leaves are deficient in sulfur-containing amino acids (e.g. methionine and cysteine) [11].

In countries where cassava is traditionally used directly for human consumption (about $70 \%$ of total cassava production), particularly in Africa and Latin America, cultivars low in cyanogens (commonly called sweet cultivars) are preferably used to avoid health hazards. When using cultivars high in cyanogens (commonly called bitter cultivars), much of the hydrocyanic acid (HCN) is normally removed from cassava roots and leaves by using a mix of complex traditional methods and modern technologies during food processing and preparation [12]. Its often poorly-processed food products contain some anti-nutrient elements such as free $\mathrm{HCN}$, phytates and polyphenols, and particularly acetone cyanohydrin, which is commonly associated with an upper motor neuron disease known as "konzo syndrome" in some African coun- tries [13-15]. This occurs mainly with large intake of inadequately processed bitter-cassava products in areas hit by long drought and with shortages of balanced diets.

Also, cassava leaves have value as a protein supplement in animal nutrition either in feed formulation for mono-gastric animals or as a fresh forage to supplement low-quality roughages in ruminant feeds [16]. All parts of cassava plants (i.e. storage roots and shoots) are valuable sources for animal feed that could be either fed or grazed fresh in case of sweet cultivars, or dried and ensilaged in bitter cultivars $[17,18]$. For decades, Thailand was the largest exporter of cassava dried root chips, mainly to European countries, where it were used as a cheap component in the industry of animal feed concentrates. A significant portion of storage roots is used worldwide for starch extraction, glucose manufacturing, alcohol, and recently for biofuel.

The cassava crop is propagated vegetative by using short woody stem cuttings (from 6-month old plants or older) planted horizontally, vertically, or inclined on flat or ridged lands at population densities from 5000 to 20,000 cuttings per hectare depending on the cropping systems and purpose of production [19,20]. Lower population densities are practiced in intercropping systems, commonly with grain legumes and cereals such as maize and sorghum. When grown in mono-cropping systems, higher densities at 10,000 plants per hectare, or greater, are used. Sexual seeds are used mainly in breeding programs, though its use in commercial cassava production is a promising option to obviate constraints, particularly diseases, associated with vegetative propagation [21]. Storage roots are generally harvested $7-24$ months after planting, depending on cultivar, purpose of use and growing conditions. Due to root perishability and rapid deterioration after harvest (within 2 - 3 days), fresh roots have to be used immediately after harvesting, either eaten on the farm, marketed for consumption, processed for starch extraction, dried for flour production, roasted for food products and/or used for animal feed. However, preharvest pruning in the three weeks before harvest decreases root deterioration because of increases in the total sugar/starch ratio in the roots [22]. Cassava processing near production fields, makes it an ideal vehicle for rural development through creating employment opportunities in the areas where it is grown. Some of the processed food products are commonly known as farinha da mandioca in Brazil and bordering countries, gablek in Indonesia, and gari and foufou in West Africa [4]. Also, in the Amazon region, local people prepare drinks such as Mingao (by dissolving fermented starch in boiling water and simmering) and Manicuera (a boiled sweet cassava drink in northwest Amazonia) [18]. Combining fresh cassava markets with those of its processed products should increase marketing flexibility and crop profitabi- 
lity, hence reducing the many risks often encountered by the producers.

\subsection{National and International Research Support}

The successes of the so-called "Green Revolution" of the 1960 's in obviating eminent famines in highly populated developing countries across continents stemmed from the development of high yielding semi-dwarf wheat cultivars at CIMMYT, the International Maize and Wheat Improvement Center established in 1963, Mexico, and the semi-dwarf rice cultivars at IRRI, the International Rice Research Institute established in the Philippines in 1960. These new highly productive cereal cultivars, under high fertilization application supplemented with irrigation, stimulated the formation in 1971 of the CGIAR, the Consultative Group on International Agricultural Research. More international research centers were established to expand activities on other staple food crops, cropping systems and natural resources management covering the most important agro-ecological zones in various developing countries $[23,24]$. In the humid and sub-humid tropics of Africa and Latin America, two new research centers concerned with cassava research were established in late 1960's: IITA, the International Institute of Tropical Agriculture, located in Nigeria, and CIAT, Centro Internacional de Agricultura Tropical, located in Colombia.

Given the necessary financial support, international multidisciplinary teams of scientists were able, for the first time, to conduct extensive research on cassava. They collaborated with the few, already existing, national research programs to improve germplasm collection and characterization, breeding, agronomy, cropping systems management, pest-and-disease control, and crop use. These activities were based on increased understanding of the physiological processes involved. Various researchers reviewed results on many aspects of cassava research in Africa, Asia, and Latin America over the last 3 decades [25-27].

In the following sections we review and highlight some of the eco-physiological research conducted at CIAT, particularly under relevant field conditions where most cassava is grown, in relation to breeding improved cultivars for both favorable and stressful environments (i.e. climatic and edaphic factors). The research had laid the foundations for cassava breeding and selection of adaptable cultivars under both environments.

\section{Cassava Research Strategy at CIAT}

At first, breeding objectives were directed towards developing high-yielding cultivars for favorable conditions where biotic and abiotic stresses were absent $[28,29]$.
This strategy focused on selecting for high yield per unit land area and comparing with traditional vigorous cultivars and/or landraces suitable for intercropping. Another trait selected for was high dry matter content (i.e. high starch content) in storage roots. Harvest indexes (HI), (where $\mathrm{HI}=$ root yield/total plant biomass) were selected to be higher than those $(<0.5)$ of common landraces and traditional cultivars [30].

However, most cassava production occurs in environments with varying degrees of stresses and with little, or no, production inputs from resource-poor farmers. Hence, later breeding strategy goals centered on selecting and developing cultivars with adequate and stable yields, and able to adapt to a wide range of biotic and abiotic stresses $[26,31,32]$. This strategy was stimulated by cassava's inherent capacity to tolerate adverse environments, particularly those where other major staple food crops such as cereals and grain legumes would fail to produce. The strategy also aimed to avoid and/or reduce the negative consequences on the environment caused when highinput (agrochemicals) production systems are adopted [4].

In light of this environmentally sound breeding strategy, research on cassava physiology has focused on both basic and applied aspects of the crop under prevailing environments. The goal was to better understand and elucidate the characteristics and mechanisms underlying productivity and tolerance of stresses [4,33-35]. It was also suggested that molecular biology tools would certainly help in achieving this goal, as would a deeper understanding of the agricultural systems and biology of tropical crops (including cassava plant physiology) [36]. "Reference [36] pointed out that temperate-zone research laboratories in OECD countries are currently not investing in such knowledge".

Objectives included 1) characterizing materials from a core collection of cassava germplasm held at CIAT for tolerance of extended water shortages, either natural or imposed, and of low-fertility soils; 2) studying leaf photosynthetic potential in relation to productivity under various edaphic/climatic conditions; and 3) identifying plant traits that may be useful in breeding programs. The multidisciplinary and inter-institutional research approach adopted was pivotal in achieving these objectives.

\section{Potential Productivity in Near Optimum Environment and Adaptability to Climate Changes}

\subsection{Potential Storage Root Yield and Leaf Photosynthetic Capacity}

Building on the knowledge and insight gained about the physiological mechanisms underlying patterns of dry matter partitioning into shoot and storage roots as related to 
leaf canopy development in cassava, [29] developed a computer-based simulation model to determine the ideal plant type for maximum yield under favorable growth conditions, both edaphic and climatic. The resulting "simulated ideal plant type" required the following characteristics: late branching at $6-9$ months from planting with no vegetative suckers, maximum leaf size near 500 $\mathrm{cm}^{2}$ per leaf blade at 4 months from planting, long leaf life of ca. 100 days, LAI (leaf area index $=\mathrm{m}^{2}$ of one surface leaf area $/ \mathrm{m}^{2}$ of surface land area) between 2.5 and 3.5 during most of the growth cycle, a harvest index (HI) greater than 0.5 , nine or more storage roots per plant at a population density of 10,000 plants/ha, and each plant having two vegetative shoots originating from the original cuttings. If this simulated ideal plant ever existed in cassava germplasm or has been genetically bred for, then it should yield in a year, according to the model predictions, about $90 \mathrm{t} / \mathrm{ha}$ of fresh roots (about $30 \mathrm{t} /$ ha dry matter), provided that the growing environment is optimal (no stress).

Confirmation of the predicted potential cassava productivity came from a maximum experimental yield of $90 \mathrm{t} /$ ha fresh roots, which was equivalent to $27 \mathrm{t} / \mathrm{ha}$ of oven-dried matter [37]. This remarkable productivity occurred in a large field trial involving several (16 accessions) improved cassava clones and breeding lines grown for 308 days in the Patia Valley, Cauca, Colombia (altitude $600 \mathrm{~m}, 2^{\circ} 09^{\prime} \mathrm{N}, 77^{\circ} 04^{\prime} \mathrm{W}$ ) with annual precipitation of $900-1000 \mathrm{~mm}, 60 \%$ of which occurred in the first three months of crop establishment, and with a pronounced dry period of three months before harvest. The climate at Patia Valley is characterized by high solar radiation (about $22 \mathrm{MJ} \cdot \mathrm{m}^{-2} \cdot \mathrm{day}^{-1}$ ), a high mean day temperature $\left(28^{\circ} \mathrm{C}\right)$, and high atmospheric humidity $(70 \%)$. These climatic factors appear to be near-optimal for high cassava productivity. Such productivity suggests that cassava has high yield potential when grown under nearoptimum conditions. Similar productivity levels, were obtained under irrigation in India [38]. Moreover, growing cassava in the seasonally dry environments of the Limpopo river basin in South Africa that experiences several months of terminal drought and winter low mid-season temperatures resulted in fresh yields in some cultivars as high as 54 and $66 \mathrm{t} /$ ha at 6 and 12 months after planting, respectively [39]. Underlying this productivity is the high photosynthetic capacity of cassava with maximum net leaf photosynthetic rates $\left(P_{N}\right)$ between 40 and 50 $\mu \mathrm{mol} \cdot \mathrm{CO}_{2} \cdot \mathrm{m}^{-2} \cdot \mathrm{s}^{-1}$ under saturating solar radiation $\left(>1800 \mu \mathrm{mol} \cdot \mathrm{m}^{-2} \cdot \mathrm{s}^{-1}\right.$ in the range of photosynthetic active radia- tion, PAR), wet soils and high atmospheric humidity [40]. These maximum $P_{N}$ are comparable with rates observed in tropical $\mathrm{C}_{4}$ crops, such as sugarcane, maize, sorghum, and millet [41]. Cassava is considered a
$\mathrm{C}_{3}-\mathrm{C}_{4}$ intermediate species based on several physiological, anatomical and biochemical leaf traits [42].

Oven-dried storage root yield across 127 accessions screened in Patia Valley, Cauca, Colombia, was significantly correlated with seasonal average upper canopy leaf $P_{N}$ [37]. It was also positively correlated with photosynthetic nitrogen use efficiency (PNUE) (Figure 1), attesting to the importance of internal leaf mesophyll characteristics such as leaf anatomy and biochemical traits.

Table 1 summarizes correlation coefficients of dry root yield of several of these accessions, where there were positive significant associations between yield and leaf $P_{N}$, PNUE, mesohphyll conductance to $\mathrm{CO}_{2}$ diffusion, as well as activity of the $\mathrm{C}_{4}$ PEPC enzyme (phosphoenolpyruvate carboxylase). Cassava leaves possess elevated PEPC activity that reaches $15 \%-25 \%$ of those in $\mathrm{C}_{4}$ tropical crops such as maize and sorghum, and much greater than activities observed in typical $\mathrm{C}_{3}$ species such as common beans [42].

These findings have important implications for cassava capacity to fix carbon, as PEPC has higher activity and more affinity to $\mathrm{CO}_{2}$ than the $\mathrm{C}_{3}$ Rubisco (Ribulose-1, 5-bisphosphatecarboxylase oxygenase), particularly at higher temperatures and soil water stress (Table 2).

Thus, selections and breeding for high $P_{N}$ and higher activities of both the $\mathrm{C}_{4}$ PEPC and the $\mathrm{C}_{3}$ Rubisco are of paramount importance for yield improvement. There are

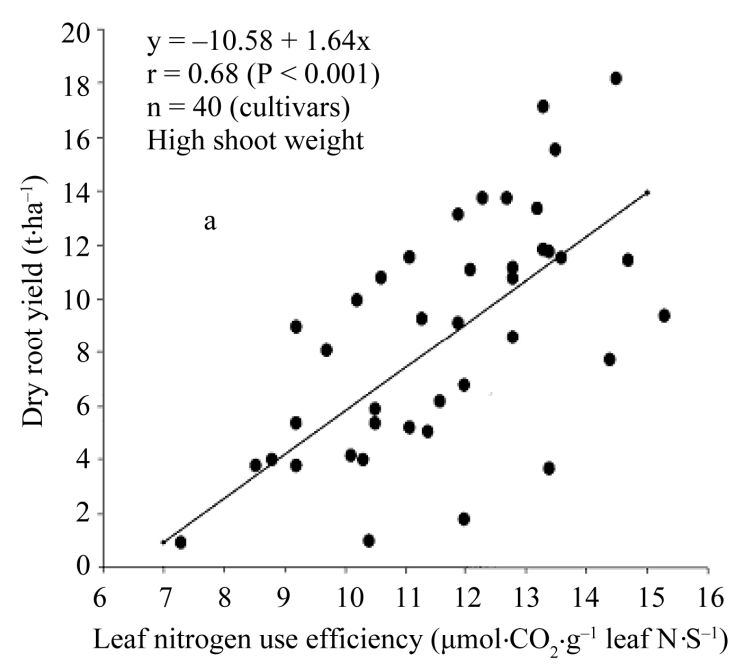

Figure 1. Relationship between oven-dried root yield (harvested 10 month after planting) and photosynthetic leaf nitrogen use efficiency in field-grown cassava at the seasonally dry Patia Valley, Cauca, Colombia. Leaf nitrogen use efficiency values were calculated from leaf $\mathrm{CO}_{2}$ exchange measurements of fully expanded upper canopy leaves during dry periods of 5 - 8 month old plants using portable infrared gas analyzers, and total leaf nitrogen content. In these accessions LAI was near optimum through much of the growing period [35]. 
Table 1. Correlation coefficients and regression equations for various plant trait combinations in 18 cultivars selected from the preliminary-screened 127 in Patia, Cauca, Colombia, 1987-1988. Leaf photosynthetic characteristics were determined in upper canopy leaves from 5 - 8 month-old-plants. Leaf nitrogen content and PEPC activity were determined in upper canopy leaves from independent leaf samples from 5-month-old-plants. Measurements were made during dry period. $n=18$ [43].

\begin{tabular}{cccc}
\hline \multicolumn{2}{c}{ Trait combination } & Correlation coefficient $(r)$ & Regression equation $(\mathrm{y}=\mathrm{a}+\mathrm{bx})$ \\
\cline { 1 - 2 }$P_{N}$ & $\mathrm{y}$ & $0.500^{*}$ & Yield $=0.178+0.047 P_{N}$ \\
PNUE & Yield & $0.481^{*}$ & Yield $=0.605+0.062$ PNUE \\
PEPC & Yield & $0.547^{*}$ & Yield $=0.804+0.057$ PEPC \\
$g_{\mathrm{m}}$ & Yield & $0.479^{*}$ & Yield $=-0.066+0.014 \mathrm{~g}_{\mathrm{m}}$ \\
PEPC & Yield & $0.597^{* *}$ & $P_{N}=18.43+0.69$ PEPC \\
PEPC & $P_{N}$ & $0.532^{*}$ & $g_{\mathrm{m}}=83.5+2.0$ PEPC \\
PEPC & $g_{\mathrm{m}}$ & $0.698^{* *}$ & PNUE $=6.42+0.58$ PEPC \\
\hline
\end{tabular}

$*$, **indicate level of significance at $P=0.05$ and 0.01 , respectively; $P_{N}=$ net leaf photosynthetic $\operatorname{rate}\left(\mu \mathrm{mol} \cdot \mathrm{CO}_{2} \cdot \mathrm{m}^{-2} \cdot \mathrm{s}^{-1}\right) ; \mathrm{PNUE}=\mathrm{photosynthetic} \mathrm{nitro-}$ gen-use efficiency $\left[\mathrm{mmol} \cdot \mathrm{CO}_{2} \cdot \mathrm{kg}^{-1} \cdot(\right.$ total leaf nitrogen $\left.) \cdot \mathrm{s}^{-1}\right] ;$ PEPC $=$ phosphoenolpyruvate carboxylase activity $\left(\mu \mathrm{mol} \cdot \mathrm{kg}^{-1} \cdot \mathrm{FM} \cdot \mathrm{s}^{-1}\right) ; g_{\mathrm{m}}=\mathrm{mesophyll} \mathrm{conduc-}$ tance to $\mathrm{CO}_{2}$ diffusion $\left(\mathrm{mmol} \cdot \mathrm{m}^{-2} \cdot \mathrm{s}^{-1}\right)$; Yield $=$ dry root yield $\left(\mathrm{kg} \cdot \mathrm{m}^{-2}\right)$; Values of cultivars (means), and ranges: $P_{N}(25.1), 21-30.6 ;$ PNUE (12.1), $9.4-16.2$; PEPC activity (9.7), 6.3 - 14.0; $g_{\mathrm{m}}(103), 93$ - 126; Yield (1.36), 1.00 - 1.83; NOTE: The significant correlations between PEPC activity and photosynthetic characteristics and yield of cassava point to the importance of the enzyme as a desirable selectable trait for cultivar improvement, particularly under stressful environments. In these trials, the average PEPC activity (9.7) in cassava was $17 \%$ of activity in the $\mathrm{C}_{4}$ grain sorghum grown on the same plot [43].

Table 2. Activities of some photosynthetic enzymes in leaf extracts of field-grown cassava as affected by 8 weeks of water stress commencing at 92 days after planting at Santander de Quilichao, 1993. Values are means \pm S.D. Activities in $\mu \mathrm{mol} / \mathrm{mg}$ $\mathrm{chl} / \mathrm{min}[44]$.

\begin{tabular}{ccccccc}
\hline \multirow{2}{*}{ Clone } & \multicolumn{3}{c}{ Unstressed } & \multicolumn{3}{c}{ Stressed } \\
\cline { 2 - 7 } & PEPC & Rubisco & PEPC/Rubisco & PEPC & Rubisco & PEPC/Rubisco \\
\hline CM 4013-1 & $0.86 \pm 0.12$ & $0.28 \pm 0.10$ & 3.10 & $1.18 \pm 0.17$ & $0.30 \pm 0.01$ & 3.9 \\
CM 4063-6 & $0.89 \pm 0.05$ & $2.30 \pm 0.03$ & 0.39 & $1.42 \pm 0.26$ & $0.62 \pm 0.02$ & 2.3 \\
SG 536-1 & $1.46 \pm 0.42$ & $0.44 \pm 0.12$ & 3.30 & $1.33 \pm 0.22$ & $0.25 \pm 0.08$ & 5.3 \\
MCol 1505 & $1.09 \pm 0.10$ & $0.57 \pm 0.13$ & 1.90 & $0.96 \pm 0.16$ & $0.89 \pm 0.14$ & 1.1 \\
Avg. & 1.08 & 0.90 & 2.2 & 1.22 & 0.52 & 3.2 \\
\% Avg. changes due to stress & & & +13 & -42 & +45 \\
\hline
\end{tabular}

NOTE: The enhancement of PEPC activity in stressed plants and the reduction in Rubisco activity which led to greater PEPC/Rubisco ratio. This finding indicates the importance of selecting for higher activity of PEPC in cassava, particularly in dry hot environments.

large variations in the activities and in the kinetic properties of these enzymes in cultivated cassava as well as in wild Manihot species, such as $M$. rubricaulis and $M$. grahami. Leaves of these wild species possess very high $P_{N}\left(>50 \mu \mathrm{mol} \cdot \mathrm{CO}_{2} \cdot \mathrm{m}^{-2} \cdot \mathrm{s}^{-1}\right)$, high PEPC activity in leaf extracts (ranged from 1.5 to $5.5 \mu \mathrm{mol}$ per mg chlorophyll per minute, compared to $6-12$ in sorghum, a $\mathrm{C}_{4}$ species, and $0.2-0.4$ in common beans, a $\mathrm{C}_{3}$ species [35]. Their leaves also have a second, but short, palisade layer on their lower surface coupled with numerous stomata on both upper and lower surface (amphistomatous leaves), traits that positively enhance $\mathrm{CO}_{2}$ uptake, as compared to the mostly hypostomatous leaves of cultivated cassava.

\subsection{Crop Adaptability to Climate Change and Responses of Leaf Photosynthesis to Temperature and $\mathrm{CO}_{2}$}

In the face of climate change/global warming trends that are predicted to adversely affect production of most food crops, such as cereals and grain legumes, in the tropics and sub-tropics, cassava role as a food, feed and biofuelcrop, will be further enhanced because of its tolerance to low-fertility soils, heat and drought stresses [4], and (Figures $\mathbf{2}$ and $\mathbf{3}$ ).

The remarkable predicted suitability of cassava to possible increases in average surface Earth's temperatures caused by expected rises in atmospheric $\mathrm{CO}_{2}$ (and perhaps other greenhouse gases) in the year 2030 and beyond (of at least $1.5^{\circ} \mathrm{C}$, although some projections are higher, depending on the Global Circulation Models used) is substantiated by the experimental data on the responses of cassava photosynthesis to temperature and $\mathrm{CO}_{2}$. Research on cassava physiology at CIAT had shown that maximum cassava growth and productivity requires high temperature $\left(>25^{\circ} \mathrm{C}\right)$, high solar radiation, high air humidity and sufficient rainfall during most of the growth 


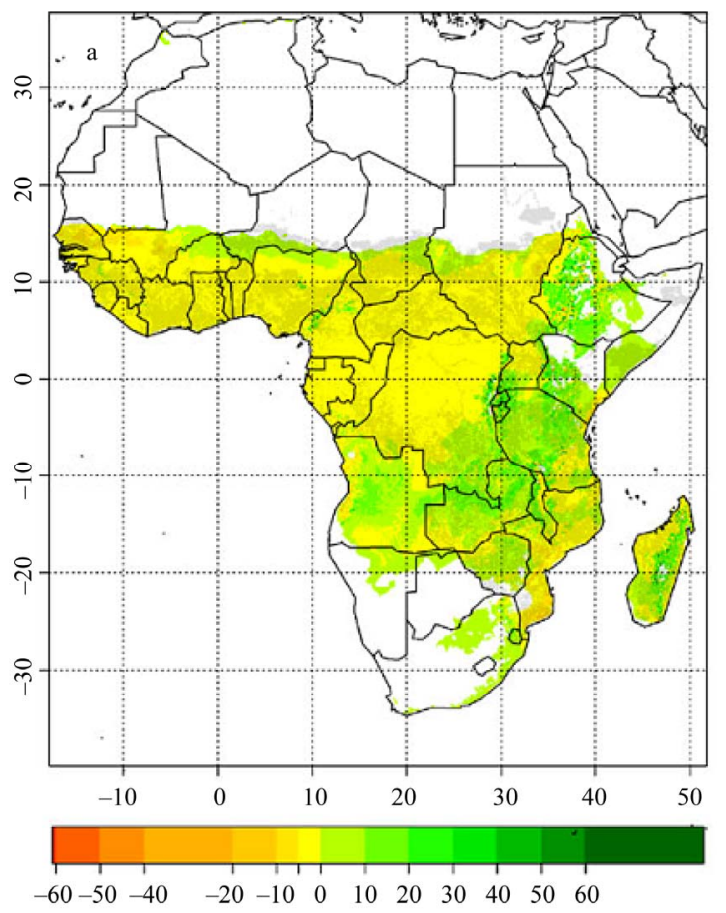

Figure 2. Predicted changes in cassava suitability in the year 2030 as average of 24 GCMs (Global Circulation Models) in sub-Saharan countries where cassava is a common crop [45].

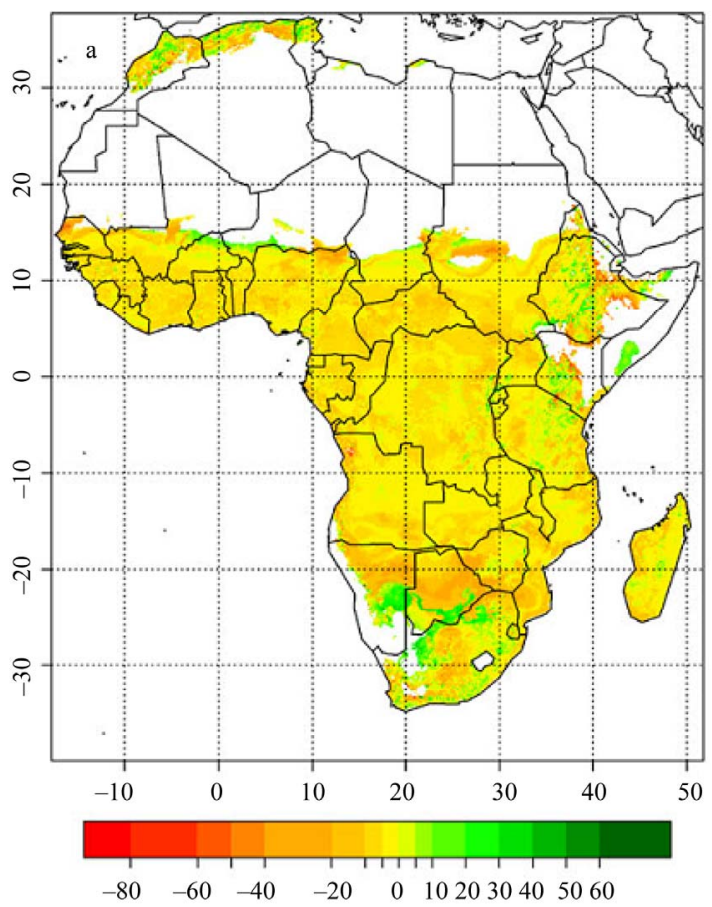

Figure 3. Predicted suitability changes in the year 2030 for maize, sorghum, millet, common beans, potato and banana, as average of 24 GCMs (Global Circulation Models), in North Africa, and sub-Saharan region [45]. NOTE: The contrasting suitability changes for these 6 food crops with that of cassava in Figure 2. period [40,42]. Figure 4 illustrates some results on the responses of leaf $P_{N}$ to gas exchange-measuring temperature in normal air (containing about $335 \mu \mathrm{mol} \mathrm{CO} / \mathrm{mol}$ ) and at near-saturation photosynthetic active radiation (PAR) for leaves that developed under cool climate (mean daily temperatures were $<20^{\circ} \mathrm{C}$ ), for cool-climate leaves that were acclimated for 7 days at warmer climate (mean daily temperature around $25^{\circ} \mathrm{C}$ ), and for leaves that were developed on the same plants in warmer climate. Also, representative responses of these sets of leaves to measuring PAR are shown in one cultivar, M Col 2059. In these trials, 8 cultivars representing cassava ecosystems, that is: hot humid low-land, hot-dry low-land, humid high altitude, and sub-tropic cool eco-zones, were tested and all had shown the same responses, indicating cassava resilient response to varying climatic conditions. Leaf photosynthesis (Figures 4(a), (b)) was lowest in cool climate leaves, and after one week of acclimation in warmer climate photosynthetic rates partially increased with an apparent upward shift in optimum temperature, particularly in the cool-humid habitat cv M Col 2059. Rates of leaves developed in warm climate were the highest, showing also an apparent upward shift in optimum temperature. Rates in all sets of leaves were greater in the hot-humid cultivar from Brazil, M Bra 12. These findings attest to the adaptability of cassava to warmer climate, and hence to its predicted suitability to future climate changes as shown in Figure 2. The adaptation of cassava photosynthetic capacity to warmer temperature is also illustrated by the lack of light saturation in warmclimate leaves (Figure 4(c)), compared to responses observed in cool-climate leaves and in cool-climate leaves acclimated for one week in warm climate.

Under field conditions at the university of Illinois, Urbana, US, using the sophisticated "Free Air Carbon Dioxide Enrichment (FACE)" method, increasing $\left[\mathrm{CO}_{2}\right]$ to $585 \mathrm{ppm}$ within canopy for 30 days (though crop growth stage was not reported) enhanced cassava leaf photosynthesis, as measured at elevated $\left[\mathrm{CO}_{2}, 585 \mathrm{ppm}\right]$, for both plants growing at ambient $\left[\mathrm{CO}_{2}, 385 \mathrm{ppm}\right]$ and elevated $\left[\mathrm{CO}_{2}, 585 \mathrm{ppm}\right]$, with the former showing greater response[46] (Figure 5). However, when leaf photosynthesis was measured at $\left[\mathrm{CO}_{2}\right]$ greater than $600 \mathrm{ppm}$, plants grown at elevated $\mathrm{CO}_{2}$ showed, over the tested external $\mathrm{CO}_{2}$ range, consistent and slightly higher rates than plants grown at ambient $\mathrm{CO}_{2}$. Such data indicate that acclimation of photosynthesis (i.e. lower maximum carboxylation capacity of Rubisco), if it occurs due to long exposure to higher than ambient $\mathrm{CO}_{2}$, may not result in reduction in cassava growth and productivity. Similar findings were reported from Venezuela using opentop chambers where cassava photosynthesis, growth and root yield of field-grown plants exposed during its entire growth period to double-ambient $\mathrm{CO}_{2}$ concentrations, 


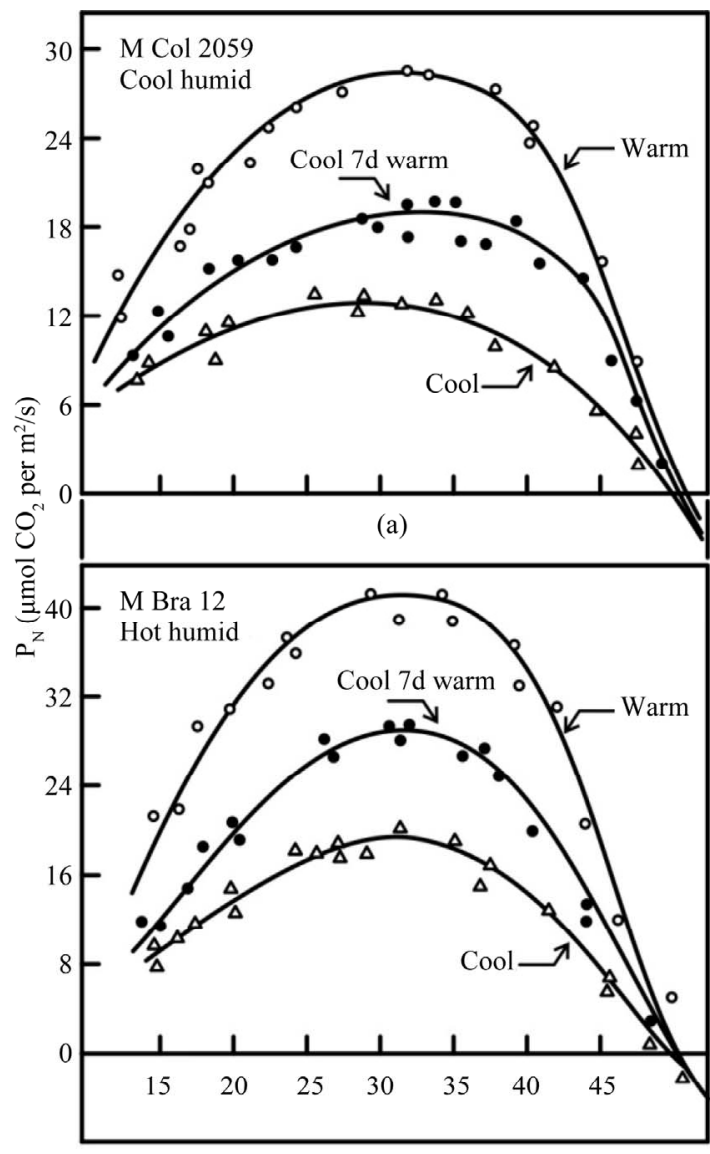

LEAF ETMPERATURE $\left({ }^{\circ} \mathrm{C}\right)$

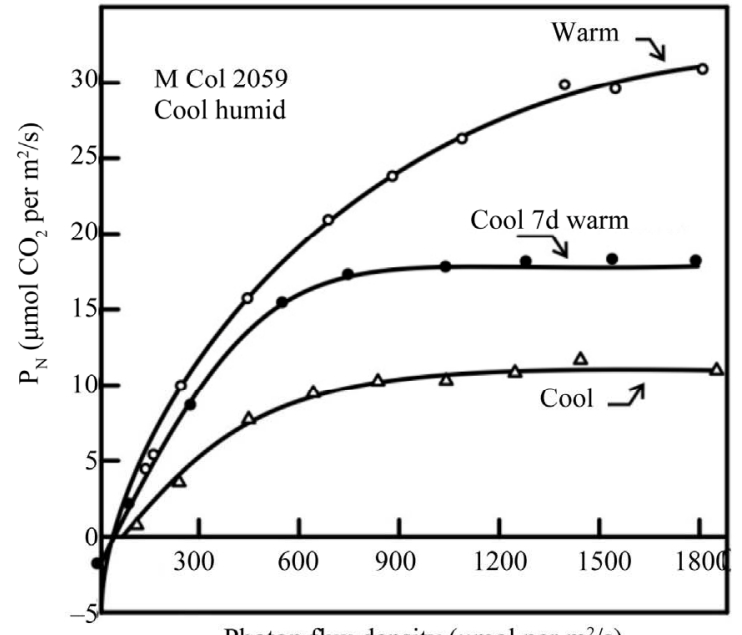

Photon flux density $\left(\mu \mathrm{mol}\right.$ per $\left.\mathrm{m}^{2} / \mathrm{s}\right)$

(c)

(b)

Figure 4. Response in terms of net photosynthetic rate $\left(P_{N}\right)$ of cassava to leaf temperature. (a) Cultivar M Col 2059 in a cool habitat; (b) cv. M Bra 12 in a hot humid habitat; (c) response in terms of net photosynthetic rate $\left(P_{N}\right)$ to PAR irradiance in cv. $M$ Col 2059. $\Delta$ refers to leaves developed in a cool climate; $\bullet$ to leaves developed in a cool climate and then acclimated for 1 week in a warm climate; o to newly developed leaves in a warm climate. Note that 1) an apparent upward shift in optimal temperature is observed from cool to warm-acclimated and warm-climate leaves; 2) the lack of light saturation in warmclimate leaves, compared with cool-and-warm-acclimated leaves; and 3) the higher maximum photosynthetic rates in all sets of leaves of cv. M Bra 12 from the hot-humid habitat, compared with the cool-climate cv. M Col 2059 [42].
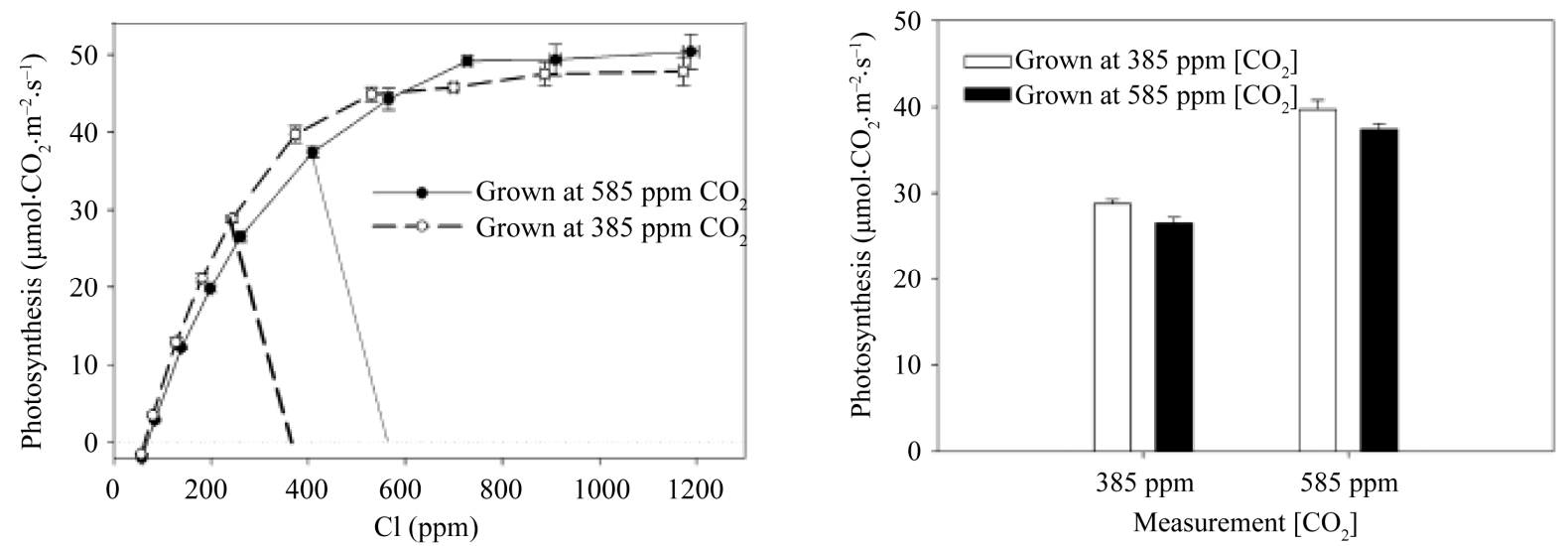

Figure 5. The response of cassava photosynthesis to $\left[\mathrm{CO}_{2}\right]$ when grown for 30 days at ambient $(385$ ppm) and elevated $(585$ ppm) $\left[\mathrm{CO}_{2}\right]$ in the field using FACE method. (Left panel) the response of photosynthesis to internal $\left[\mathrm{CO}_{2}\right](\mathrm{Ci})$. The dashed and solid straight lines intersect the $\mathrm{x}$-axis at the growth $\left[\mathrm{CO}_{2}\right]$ of the plants used to measure these curves. (Right panel) instantaneous photosynthesis for ambient-and-elevated $\mathrm{CO}_{2}$ grown plants measured at their respective growth $\left[\mathrm{CO}_{2}\right]$, [46]. 
were significantly greater than those in ambient $\mathrm{CO}_{2}$ grown plants [47]. Also, greenhouse-grown cassava under elevated $\mathrm{CO}_{2}$ at USDA-ARS labs in Maryland, US, had greeter photosynthesis, biomass and yield, compared to ambient $\mathrm{CO}_{2}$ level-grown cassava [48]. These findings contradict reports from Australia on potted indoor-grown cassava, where leaf photosynthesis, plant growth and storage roots were reduced in plants grown in elevated $\mathrm{CO}_{2}$, compared to plants grown under ambient $\mathrm{CO}_{2}$ [49]. Cassava is a shrub that requires large volume of soils for storage root development and filling, and therefore, in the Australian experiments there were apparently feedback inhibition of leaf photosynthesis due to restricted root-sinks. Moreover, cassava plant is resilient in nature with plasticity in its growth habits forming several branches on main stems associated with reproductive organs (i.e. flowers, fruits and seeds) in most cultivars, thus, providing alternative sinks (in addition to its starchy storage roots) for extra photo-assimilates [29,33,35,50-52]. This type of growth and phenology behavior with multiple and larger sink demands for photo-assimilates should enhance leaf photosynthesis under elevated $\mathrm{CO}_{2}$ and, hence, could lead to greater total biomass and yield [53, 54]. Using the EPIC crop model to assess the impact of climate change on cassava adaptability and productivity in marginal lands of northeastern Thailand, Sangpenchan [55] reported that cassava grown in water-limited areas would benefit from the so-called " $\mathrm{CO}_{2}$ fertilization" contribution when combined with improved production technologies. Moreover, the crop would likely respond to rising $\mathrm{CO}_{2}$ by decreasing its evapotranspiration rate because of its tight stomatal control mechanism [42] and, hence, increasing the efficiency with which it used limited water supply predicted with climate changes.

\section{Response of Cassava to Air Humidity and Prolonged Soil Water Shortage}

\subsection{Response to Air Humidity under Controlled Laboratory Conditions and in Field}

When cassava leaves were exposed to dry air under laboratory conditions, their stomata closed in both well-watered and stressed plants without changes in leaf water potential (Figure 6(a)). Transpiration initially increased with rising leaf-to-air vapor pressure deficit (VPD) up to $2 \mathrm{kPa}$ and then declined with further increases (Figure 6(b)). Such response contrasts with transpiration in maize leaves where transpiration increased with rising VPD. The closure of cassava stomata reduced also $P_{N}$ beyond $1.5 \mathrm{kPa}$ [56]. At canopy level in wet soils, raising air humidity via fine misting enhanced $P_{N}$ (Figure 6(c)) that led to increases in storage roots [57,58]. The striking response to humidity is a "stress avoidance mechanism" that underlies cassava conservative water use, particularly
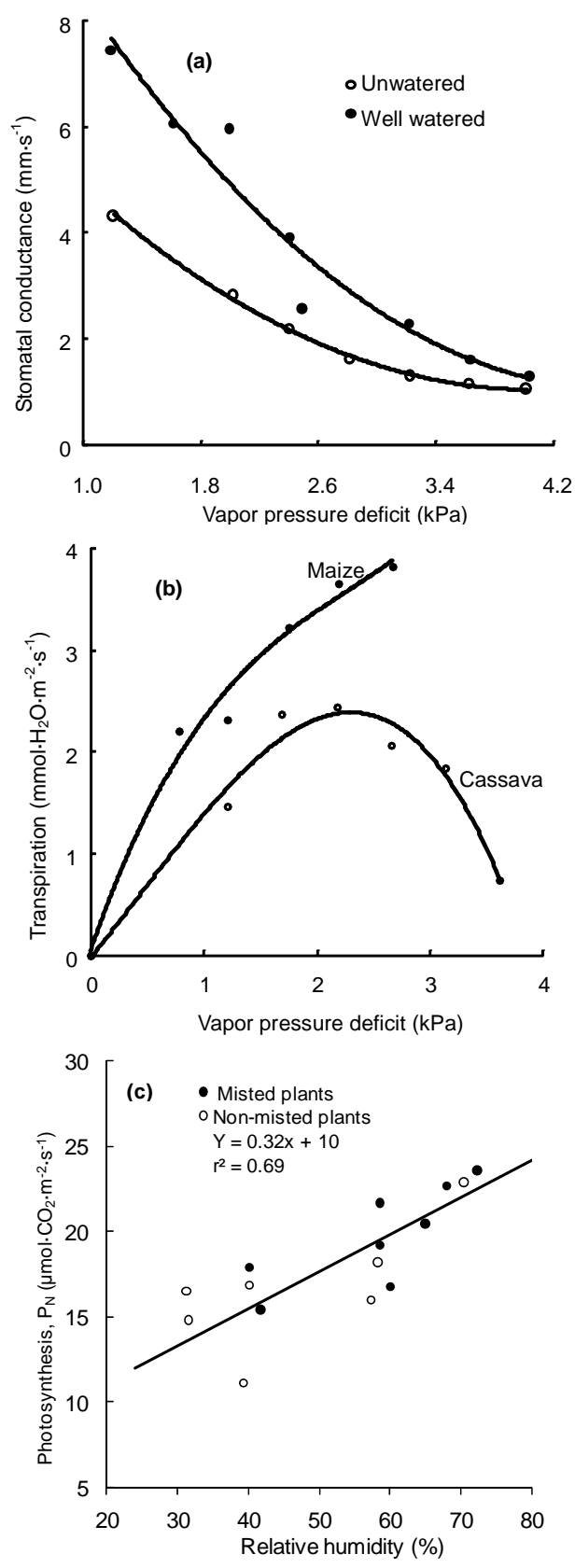

Figure 6. Response of cassava to atmospheric humidity. (a) Effect of leaf-to-air vapor pressure deficit on stomatal conductance in well-watered and water-stressed cassava. Note the rapid decline in stomatal conductance, as an indication of stomatal closure, on exposure to low humidity irrespective of soil water conditions. Leaf water potential remained unchanged in both well-watered plants (ca. $-0.8 \mathrm{MPa}$ ) and the water-stressed plants (ca. $-1.2 \mathrm{MPa}$ ) during exposure to low humidity; (b) Effect of leaf-to-air vapor pressure deficit on transpiration of cassava and maize leaves. Note the sharp decline in transpiration rates of cassava at large vapor pressure deficit as compared with rates of maize; (c) Effect of air humidity on leaf photosynthesis of field-grown cassava, with and without misting. The soils were wet in both crops. Note the strong correlation in $\boldsymbol{P}_{N}$ vs. RH. Sources: (a), (b), [58]; (c), [57]. 
under soil water deficits, an advantage as compared to less sensitive species such as maize.

\subsection{Responses of Field-Grown Cassava to Prolonged Water Shortages at Different Growth Stages and Implications for Nutrient and Crop Water Use}

Two-year field trials were conducted under prolonged early water stress (occurring 2 - 6 months after planting); mid-season stress ( 4 - 8 months after planting), and terminal (i.e., end-of-season) stress (6 - 12 months after planting). Table 3 presents data on root yield, shoot and total biomass at 12 months, and nutrient use efficiency in terms of root production. On one hand, water stress reduced shoot biomass in all stages but reduction was significant only in early stress. On the other hand, final root yield across clones was not significantly reduced at any water shortage treatment. However, at the end of early and mid-season stress both shoot and storage root were significantly reduced, but recovered after release from stress. This response demonstrates the resilience of cassava and its adaptability to prolonged water stress.

Water stress enhanced nutrient use efficiency in terms of storage root production in both early and mid-season stress because of the great reduction in shoot biomass, relative to roots, and hence, lesser total nutrient uptake [59]. This response is beneficial for soil management where cassava producers rarely apply purchased agroche- micals.

Another trait that underlies cassava tolerance to extended water stress, is its ability to extract water from deeper wet layers of soils (Figure 7). Combined with stomatal sensitivity to atmospheric humidity, deeper rooting system increases tolerance to drought and result in higher crop water use efficiency, compared to some other crops (Table 4).

The findings on the effect of water stress on nutrient use efficiency due to less nutrient uptake by lesser shoot biomass had led to the search for genotypes that differ in their architecture in relation to nutrient use efficiency. In a two-year field trials, a group of 15 clones that differed in their height, top biomass, and LAI were grown in absence of soil water shortage and with adequate fertilizer $[42,60]$. In this group, short-stemmed cassava showed root yields that approached the tall cassava with tendency to early storage root filling. Total nutrient uptake was less in short-stemmed cassava resulting in higher nutrient use efficiency in terms of root production (Table 5). Short cassava possessed lower LAI, lower shoot biomass and higher $P_{N}$, as compared with tall cassava. The LAI in short-stemmed cassava was lower than the optimum required for efficient light interception, and hence, less productivity when planted at 10,000 plant per hectare. At higher population densities, short cassava may out-yield tall ones. In low fertility soils, where cassava normally is grown without fertilization, short cassava is beneficial

Table 3. Effect of water stress on 12-month yield, biomass and nutrient use efficiency (NUE) for storage root production (kg dry roots/kg total nutrient uptake). Fallen leaves were excluded. Data are means of four clones in two years, [59].

\begin{tabular}{ccccccccc}
\hline Water regime & Dry total biomass (t/ha) & Dry roots (t/ha) & Dry shoots (t/ha) & $\mathrm{N}$ & $\mathrm{P}$ & $\mathrm{K}$ & $\mathrm{Ca}$ & $\mathrm{Mg}$ \\
\hline Control & 18.9 & 12.9 & 6.0 & 120 & 660 & 110 & 300 & 440 \\
Early stress & 14.5 & 11.2 & 3.3 & 150 & 940 & 150 & 360 & 650 \\
Mid-season stress & 18.0 & 12.9 & 5.1 & 120 & 840 & 140 & 330 & 530 \\
Terminal stress & 16.9 & 11.7 & 5.2 & 110 & 690 & 120 & 300 & 520 \\
LSD 5\% & 2.3 & $\mathrm{NS}^{*}$ & 1.4 & 12 & 70 & 9 & 50 & 65 \\
\hline
\end{tabular}

"NS = Not significant at 5\%; Control: crop was well watered; Early stress: crop was deprived of water between 2 months to 6 months after planting; Mid-season stress: crop was deprived of water between 4 months to 8 months after planting; Terminal stress: crop was deprived of water from 6 months after planting until harvest at 12 months.

Table 4. Comparative water use efficiency (WUE) of cassava, grain sorghum and common bean [58].

\begin{tabular}{cccc}
\hline Species & single-leaf gas exchange & WUE & field-grown crops \\
& $\mu \mathrm{mol} \mathrm{CO} \mathrm{CO}_{2} \cdot \mathrm{mmol}^{-1} \mathrm{H}_{2} \mathrm{O}$ & $\mathrm{g}$ dry weight $\cdot \mathrm{kg}^{-1} \mathrm{H}_{2} \mathrm{O}$ & $\begin{array}{c}\text { economic yield } \\
\mathrm{g} \text { dry weight } \cdot \mathrm{kg}^{-1} \mathrm{H}_{2} \mathrm{O}\end{array}$ \\
\hline Cassava & 5.3 & 2.9 & $1.7(\mathrm{HI} 60 \%)^{\dagger}$ \\
Sorghum & 6.2 & 3.1 & $1.2(\mathrm{HI} 40 \%)$ \\
Common bean & 3.5 & 1.7 & $0.7(\mathrm{HI} 40 \%)$ \\
Cassava/sorghum (\%) & 85 & 94 & 140 \\
Cassava/common bean (\%) & 150 & 170 & 240 \\
\hline
\end{tabular}

${ }^{\dagger} \mathrm{HI}$ : harvest index $=($ dry grain or dry storage root $) /($ total dry weight $) \times 100$. 
Table 5. Nutrient use efficiency (NUE) for root production at 10 months after planting [ $\mathrm{kg}\left(\mathrm{dry}\right.$ root) $\mathrm{kg}^{-1}$ (total nutrient uptake)] for groups of tall and short cassava cultivars [42,60]. Data are averages of several cultivars in two years within each plant type group.

\begin{tabular}{|c|c|c|c|c|c|}
\hline Plant Type & $\mathrm{N}$ & $\mathrm{P}$ & $\mathrm{K}$ & $\mathrm{Ca}$ & $\mathrm{Mg}$ \\
\hline Tall & 110 & 715 & 132 & 347 & 589 \\
\hline Short & 131 & 885 & 161 & 430 & 669 \\
\hline LSD 5\% & 17 & 85 & 22 & 77 & 91 \\
\hline
\end{tabular}

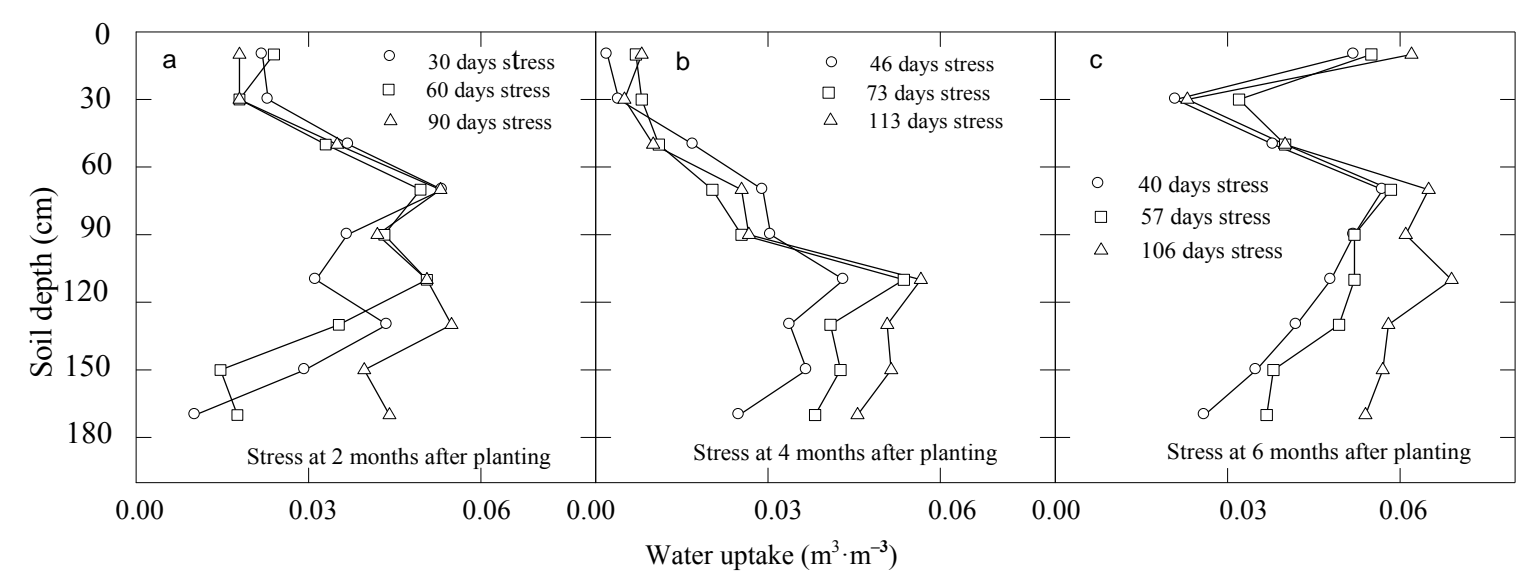

Figure 7. Patterns of water uptake as average of four cassava cultivars during extended periods of water deficits of different lengths, Santander de Quilichao, department of Cauca, Colombia. Note the greater water extraction from deeper soil layers that increased as water stress progressed over time, particularly in terminally stressed crops (C) [42].

for soil fertility management when grown at high population density to increase canopy light interception, and hence, productivity. The higher nutrient uptake in tall cassava was the reason for its lower nutrient use efficiency. In most cassava regions, farmers don't recycle the crop residue to the soil after harvest, thus a significant amount of nutrients are removed. It was reported in Kerala state, southern India, that under sufficient rainfall ( $>1500 \mathrm{~mm}$ in 10 months), the short duration improved cultivar, namely Sree Vijaya (6 months duration and high HI, released in 1998), had greater yield and greater NUE in terms of storage root production per unit of nitrogen uptake than the traditional cultivar, namely M-4 (10 month duration and low HI) [61]. It appears that for soil conservation and better use of nutrient in cassava cropping systems, the choice of cultivar is an important approach. Therefore, breeding for short-to-medium stature genotypes is warranted.

\section{Comparative Advantage of Cassava versus Other Food and Energy Crops}

\subsection{Performance of Cassava as a Source for Food Energy and Biofuel in Comparison with Some Important Food and Energy Crops}

In absence of production constraints under near-optimum environments, cassava potential productivity is quite large that might reach $>80 \mathrm{t} / \mathrm{ha}$ fresh roots annually [4,37]. For example, in the Patia Valley, Cauca Department, Colombia, which is near ideal low-land tropical eco-zone for cassava production, yields as high as $90 \mathrm{t} / \mathrm{ha}$ in 308 days (equivalent to $27 \mathrm{t} /$ ha oven-dried dry matter) were obtained with a group of improved clones. Table 6 summarizes energy yields for cassava and some other food crops based on maximum observed yields. It is apparent that cassava compares favorably in terms of energy yield with other major staple food crops while having the greatest potential. Experimental energy productivity in cassava exceeds that observed in the most productive $\mathrm{C}_{4}$ warm climate cereals, such as maize and grain sorghum, as well as the tropical $\mathrm{C}_{3}$ rice, but less than sugarcane. Moreover, cassava inherent tolerance to abiotic stresses (e.g. poor soils and prolonged drought coupled with high temperatures) allows the crop to be sustainably productive in adverse environments where most other staple food crops would fail to produce reasonable yields $[4,5]$. This advantage is illustrated by the superior predicted suitability of cassava against several tropical food crops in the face of expected climate changes in coming decades (see Figures 2 and 3) [45].

This inherent biological ability to produce very high yields of starchy roots in near optimum environments, as well as its remarkable tolerance to adverse conditions, recently have made the crop a desired source for renewable energy in many countries where it is commonly 
Table 6. Maximum recorded yield and food energy production of some important tropical food crops.

\begin{tabular}{cccc}
\hline Crop species & Annual yield (t/ha) & Daily energy yield (kcal/ha) $^{\mathrm{a}}$ & Daily energy yield (kj/ha) $^{\mathrm{b}}$ \\
\hline Cassava (fresh storage roots) & 71 & 250 & 1045 \\
Maize(dry grain, 10\% moisture) & 20 & 200 & 836 \\
Sweet potato (fresh storage roots) & 65 & 180 & 752 \\
Paddy rice (dry grain, 10\% moisture) & 26 & 176 & 652 \\
Sorghum(dry grain, 10\% moisture) & 13 & 114 & 477 \\
Wheat(dry grain, 10\% moisture) & 12 & 110 & 460 \\
Banana(fresh fruit) & 39 & 80 & 334 \\
\hline
\end{tabular}

Estimates from: (a) [62]; (b) [35].

produced, including Thailand [63], a traditionally cassava exporting country, and China $[64,65]$ where a currently high demand for fuels exists. In the past decade, cassava-derived bioethanol production has been increasing due to its economic advantages, compared to other bioethanol-source crops as shown in Table 7. Also, cassava can be grown on marginal lands that do not support production of food crops, particularly cereals, thus obviating competition with the need for food. The potential yield of bioethanol is apparently higher in cassava than for any other plant species, including the traditional bioethanol source crops such as maize, sweet sorghum and sugarcane. However, the gap between the potential experimental yields of cassava and the actual yields on farmers' fields is more than fivefold [4,5]. With the exception of India, current farmers' yields as low as $6-8$ $\mathrm{t} / \mathrm{ha}$ exists in Africa and as high as $13-18 \mathrm{t} / \mathrm{ha}$ occurs in some Asian and Latin American countries. These low yields are normally attained with local, traditional varieties grown on marginal soils without the application of purchased agrochemicals. The expected higher demands in developing countries for cassava products as food, feed, and industrial uses in the face of climate changes would call for the removal of the many socioeconomic constraints on cassava production, uses and marketing. Moreover, since the cassava plant has inherently high leaf photosynthetic capacity in current air and at high temperature coupled with high solar irradiances [40,42], also (see Figure 4), and responds positively to elevated $\mathrm{CO}_{2}$ (see Figure 5), possible future expansion in cassava cultivation may enhance atmospheric carbon sequestration, and hence helps mitigating adverse effects of globally warming climate [66]. Under the predicted $\mathrm{CO}_{2}$ rises in this century (up to 700 ppm by some GCMs [67]), cassava may be one of the few tropical food crops that can adapt to this climatic changes by shifting upward its optimum temperature for photosynthesis, growth and production. Most crops increase their WUE in elevated $\mathrm{CO}_{2}$ environments, particularly under water deficits [68], due to both higher carbon uptake and lower stomatal conductance to gas diffusion that lead to less transpira- tion water losses. Cassava is equipped with a tight stomatal control mechanism over gas exchanges, which is more sensitive to changes in air humidity and soil water status than other crops [4,35,42,56-69], also (see Figure 6), making it highly efficient in water use (see Table 4).

\subsection{Comparative Soil Nutrient Extraction by Cassava and Other Food Crops}

In contrast with the high-input technology used in the Green Revolution crops (i.e. rice, wheat and maize), most of cassava production in the tropical and subtropical agro-ecosystems is done by resource-poor small farmers on marginal lands, with often degraded soils, virtually without application of purchased agrochemicals $[4,5$, 71]. Cassava is tolerant to tropical highly leached acidic soils low in $\mathrm{pH}$, high in exchangeable aluminum and particularly low in phosphorus (P) [50,70-72]. Mid-term cassava responses in infertile sandy soils in northern Colombia (private farm) (Figure 8), and long-term responses to acidic clayey soils low in nutrient contents at CIAT Experimental Station, Santander de Quilichao (Figure 9), illustrate both the level of tolerance of cassava to poor soils and the positive responses to fertilization. In the sandy soils (Figure 8), cassava kept producing $>2 \mathrm{t} /$ ha oven-dried storage roots without fertilization during several consecutive cropping cycles, with noted differences among cultivars (the highest tolerance level and greatest response to NPK fertilizers were in cultivar M BRA 191). In the acidic clayey soils (Figure 9), cassava kept producing during 6 years of consecutive cropping reasonable yields ( $>15 \mathrm{t} / \mathrm{ha}$ fresh storage roots) in absence of application of any major element, i.e. N, P, and $\mathrm{K}$. There were positive responses to applications of these elements, with the largest responses observed with the application of K. At 12 years of consecutive cultivation in this trial, dry root yields in absence of $\mathrm{N}$ application, but with $\mathrm{P}$ and $\mathrm{K}$, were $7.9 \mathrm{t} /$ ha for $\mathrm{M} \mathrm{Col} \mathrm{1684,} \mathrm{and}$ $4.7 \mathrm{t} /$ ha for $\mathrm{CM}$ 91-3. In absence of $\mathrm{P}$ application, but with $\mathrm{N}$ and $\mathrm{K}$, dry root yields at the $12^{\text {th }}$ year were 6.1 and $4.7 \mathrm{t} / \mathrm{ha}$, for M Col 1684 and CM 91-3, respectively. 
Table 7. Comparative advantage of cassava as a potential biofuel crop versus other energy crops [65]. Yield estimates are based on favorable production conditions.

\begin{tabular}{cccc}
\hline Crop species & Annual average yield (t/ha) & Conversion rate to bioethanol (Liter/t) & Annual bioethanol yield (Liter/ha) \\
\hline Cassava & 40 (fresh storage roots) & 150 & 6000 \\
Sugarcane & 70 (fresh canes) & 70 & 4900 \\
Sweet sorghum & 35 (biomass) & 80 & 2800 \\
Rice & 5 (grain) & 450 & 2250 \\
Maize & 5 (grain) & 410 & 2050 \\
Wheat & 4 (grain) & 390 & 1560 \\
\hline
\end{tabular}

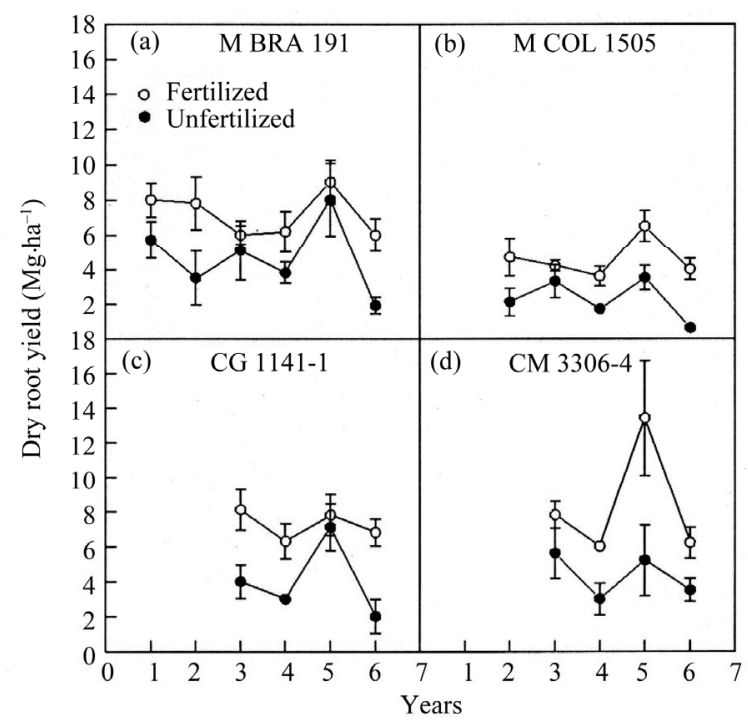

Figure 8. Mid-term response of cassava to fertilizer in sandy poor soil, Media Luna, Magdalena, Colombia. The fertilized treatment received annually $50 \mathrm{~kg} \mathrm{~N}, 20 \mathrm{~kg} \mathrm{P}$, and 43 $\mathrm{kg} \mathrm{K} / \mathrm{ha}$. (a) cv. M BRA 191, from hot-dry low-land Brazil; (b) cv. M COL 1505, local variety in northern Colombia; (c) CG 1141-1, and (d) CM 3306-4, CIAT breeding lines, which out-yielded the local cultivar M Col 1505 [73].

Without $\mathrm{K}$ application until the $12^{\text {th }}$ year, but with $\mathrm{N}$ and $\mathrm{P}$, yields were extremely low at 2.9 and $1.7 \mathrm{t} / \mathrm{ha}$ dry matter for M Col 1684 and CM 91-3, respectively. This was due to the removal of more than $70 \%$ of absorbed $\mathrm{K}$ along with the harvested starchy roots, indicating that $\mathrm{K}$ is the most critical nutrient. However, in absence of annual application of the three nutrients $(\mathrm{N}, \mathrm{P}, \mathrm{K})$ during 12 years of consecutive cropping, oven-dried storage root yields remained at $2.9 \mathrm{t} / \mathrm{ha}$ for $\mathrm{M} \mathrm{Col} 1684$ and 2.1 for CM 91-3, attesting to cassava high tolerance to exhausted acidic soils. Noteworthy, in absence of NPK fertilization, production of reproductive organs (flowers, fruits and seeds) was enhanced, and HI increased, indicating phenology changes in cassava growing on infertile soils as previously observed [50].

Without NPK applications for 12 years, average seasonal $P_{N}$ of upper canopy leaves, as measured with photosynthetic active radiation $>1000 \mu \mathrm{mol} \cdot \mathrm{m}^{-2} \cdot \mathrm{s}^{-1}$ and in
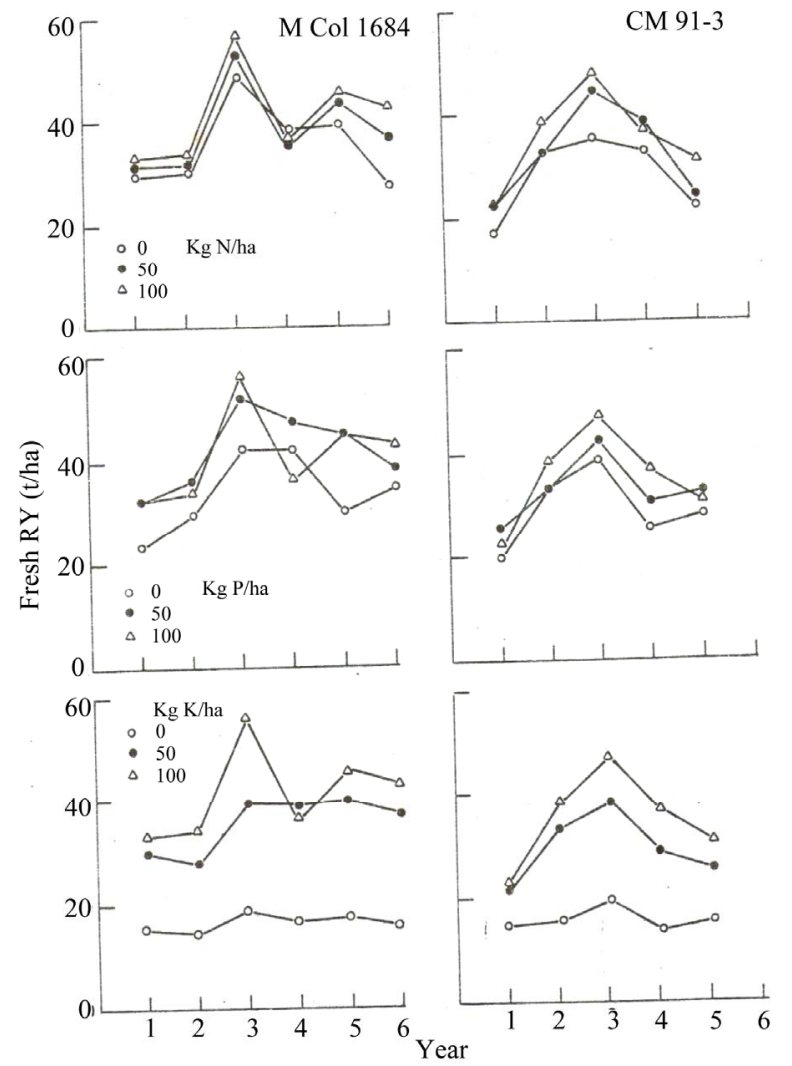

Figure 9. Long-term response of cassava (cv. M Col 1684 and CM 91-3) to NPK fertilizer in a low-fertility acidic clayey soil at Santander de Quilichao, Cauca, Colombia. Note that the greatest limitation to cassava production was K [74].

normal air having $350 \mathrm{ppm}$, was around $20-25 \mu \mathrm{mol}$ $\mathrm{CO}_{2} \mathrm{~m}^{-2} \cdot \mathrm{s}^{-1}$, compared to $30-35 \mu \mathrm{mol} \mathrm{CO} \mathrm{m}^{-2} \cdot \mathrm{s}^{-1}$ in plants receiving annually $100 \mathrm{~kg} / \mathrm{ha}$ each $\mathrm{N}, \mathrm{P}$ and $\mathrm{K}$. The leaf photosynthetic capacity in cassava remains remarkably high, compared to other warm-climate legume (e.g. common beans, $\mathrm{C}_{3}$ ) and cereal (e.g. maize, $\mathrm{C}_{4}$ ) food crops, under extremely low soil nutritional status, which may underlie its ability to sustain reasonable yields [34, $50,74,75]$. Another plant trait that may explain the reasonable carbon uptake rates in absence of NPK application was the lower leaf area per plant as well as lower 
LAI because of restricted new leaf formation with smaller size and lower specific leaf area (leaf area/unit leaf weight) $[34,50]$, thus allowing concentrated and sustainable leaf NPK contents. In these soils, it appears that the limitation to cassava storage root production, when grown continuously for long period on the same land, are in decreasing order: $\mathrm{K}>\mathrm{P}>\mathrm{N}$. Very few, if any, food crops will tolerate such poor soils and be able to produce reasonably without fertilization, compared to cassava. This comparative advantage in favor of cassava have led many to erroneously believe that cassava removes high volumes of nutrients, and hence renders the already poor soil unsuitable for cultivation of other food crops.

Table 8 presents the average extracted quantities of major nutrients by cassava storage roots and by harvested yields of other food crops. It is clear from these data that cassava removed less $\mathrm{N}$ and $\mathrm{P}$ per ton of dry root than values in harvested products of other crops. Removal of $\mathrm{K}$ was either similar or lower than some other crops. Because of the high yield in cassava, the crop removed equal amounts of $\mathrm{N}$ and $\mathrm{P}$ per hectare as with other crops. However, cassava removed more $\mathrm{K}$ per hectare than any other crop, as $>70 \%$ absorbed $\mathrm{K}$ is removed in storage roots. Thus, the negative reputation concerning cassava cultivation as a cause of soil degradation is not based on sound scientific facts as illustrated here and in published literature. Cassava is very resilient and highly tolerant to abiotic stresses, an advantage over many other staple food crops as shown by its higher predicted suitability to climatic changes (see Figures $\mathbf{2}$ and $\mathbf{3}$ ).

\section{Selection for Tolerance of Low Fertility Acidic Soils}

\subsection{Rational}

As most cassava production by smallholders occurs in marginal lands with low levels of soil fertility [4,5], cassava breeding strategy at CIAT focused on selection for adaptation to farmer's field conditions $[4,31,34,77]$. Cassava soil-and-plant nutrition management section [70,71], and later cassava physiology section $[4,34,35,42,50,56$, 72], oriented their research objects toward characterization of CIAT cassava germplasm in response to infertile, low-P, acidic soils in the South American tropics. From 1982 to 1996 , more than 1800 accessions, including land races, common varieties and elite CIAT breeding lines have been evaluated for responses to $\mathrm{P}$, and many clones with high level of adaptation to low P (and with high response to $\mathrm{P}$ application) have been identified and included in crop improvement program [44,50,72-75,77, 78]. Later several dozens of cassava core germplasm have also been tested for their tolerance to low-K soils, with few clones with high level of tolerance have been identified $[79,80]$. In the following subsections, data of many tested accessions for their tolerance of low-P and low-K soils, as well as responses to $\mathrm{P}$ or $\mathrm{K}$ fertilizer application, are presented.

\subsection{Performance of Some Cassava Clones at Zero and $75 \mathrm{kgP} / \mathrm{ha}$}

For screening large accessions for response to low fertility soils, we adopted a simple field method to test at two levels of P, i.e., zero and $75 \mathrm{kgP} / \mathrm{ha}$. A calculated adaptation index to low $\mathrm{P}$, taking into account yields of a given clone in relation to the overall mean of the trial at both low and adequate levels of applied $\mathrm{P}$ fertilizer, indicates the degree of tolerance. Data of a group composed of 33 clones from CIAT core germplasm, including land races, common varieties and advanced breeding materials, that were tested for three years are presented in Figure 10, and in Table 9. Clones with low-P adaptation index above the overall mean of the trial (1.0), have been identified as having a reasonable degree of tolerance. In this group, there were 13 clones with high and moderate degree of tolerance, with several CIAT breeding materials

Table 8. Representative dry yield (t/ha), and major nutrient extraction estimates from soils, as expressed in $\mathrm{kg} / \mathrm{ha}$ and $\mathrm{kg} / \mathrm{t}$ of harvested yield, for cassava and some other staple tropical crops [70,71].

\begin{tabular}{|c|c|c|c|c|c|c|c|}
\hline Crop species & Dry yield (t/ha) & $\mathrm{N}(\mathrm{kg} / \mathrm{ha})$ & $\mathrm{P}(\mathrm{kg} / \mathrm{ha})$ & $\mathrm{K}(\mathrm{kg} / \mathrm{ha})$ & $\mathrm{N}(\mathrm{kg} / \mathrm{t})$ & $\mathrm{P}(\mathrm{kg} / \mathrm{t})$ & $\mathrm{K}(\mathrm{kg} / \mathrm{t})$ \\
\hline Cassava (storage roots) & 13.53 & 55 & 13.2 & 112 & 4.5 & 0.83 & 6.6 \\
\hline Sweet potatoes (storage roots) & 5.05 & 61 & 13.3 & 97 & 12.0 & 2.63 & 19.2 \\
\hline Sugarcane (cane) & 19.55 & 43 & 20.2 & 96 & 2.3 & 0.91 & 4.4 \\
\hline Maize(grain) & 5.56 & 96 & 17.4 & 26 & 17.3 & 3.13 & 4.7 \\
\hline Sorghum (grain) & 3.10 & 134 & 29.0 & 29 & 43.3 & 9.40 & 9.4 \\
\hline Paddy rice (grain) & 3.97 & 60 & 7.5 & 13 & 17.1 & 2.40 & 4.1 \\
\hline Soybeans (grain) & 0.86 & 60 & 15.3 & 67 & 69.8 & 17.79 & 77.9 \\
\hline Common beans (grain) & 0.94 & 37 & 3.6 & 22 & 39.6 & 3.83 & 23.4 \\
\hline Groundnuts (pod) & 1.29 & 105 & 6.5 & 35 & 81.4 & 5.04 & 27.1 \\
\hline Tobacco (leaves) & 2.10 & 52 & 6.1 & 105 & 24.8 & 2.90 & 50.0 \\
\hline
\end{tabular}


Table 9. Dry root yield of cassava as affected by phosphorus application, and Low-P adaptation index for some cassava clones (mean of 3 years). Source: M. A. El-Sharkawy, unpublished.

\begin{tabular}{cccc}
\hline Clone & Zero kg P/ha dry root yield (t/ha) & 75 kg P/ha dry root yield (t/ha) & Low-P adaptation index \\
\hline SG 779-9 & 7.3 & 11.4 & 1.8 HA $^{\mathrm{b}}$ \\
CM 5830-4 & 7.3 & 11.2 & $1.7 \mathrm{HA}^{\mathrm{a}}$ \\
CG 333-4 & 7.2 & 10.7 & $1.6 \mathrm{HA}$ \\
CG 5-79 & 7.5 & 10.1 & $1.6 \mathrm{HA}$ \\
CM 4774-2 & 6.9 & 10.6 & $1.5 \mathrm{HA}$ \\
CM 3555-6 & 6.2 & 10.4 & $1.4 \mathrm{MA}^{\mathrm{c}}$ \\
M BRA 390 & 6.8 & 9.7 & $1.4 \mathrm{MA}$ \\
SM 366-2 & 6.5 & 10.4 & $1.4 \mathrm{MA}$ \\
CG 95-1 & 7.0 & 8.5 & $1.3 \mathrm{MA}$ \\
CG 1355-2 & 6.1 & 10.4 & $1.3 \mathrm{MA}$ \\
CG 996-6 & 5.6 & 10.6 & $1.3 \mathrm{MA}$ \\
M BRA 589 & 5.7 & 10.4 & $1.3 \mathrm{MA}$ \\
SM 380-3 & 5.6 & 11.2 & $\mathbf{8 . 8}$ \\
Mean of trial (33 clones) & $\mathbf{5 . 4}$ & 1.7 & $1.3 \mathrm{MA}$
\end{tabular}

a) Low-P adaptation index $\left.=\frac{(\text { Dry root yield at zero } \mathrm{P})(\text { Dry root yield at } 75 \mathrm{~kg} \mathrm{P} / \mathrm{ha})}{(\text { Mean clones dry root yield at zero } \mathrm{P})(\text { Mean clones dry root yield at } 75 \mathrm{~kg} \mathrm{P} / \text { ha })} ; \mathrm{b}\right) \mathrm{HA}=\mathrm{High}$ adaptation; c) MA $=\mathrm{Moderate}$ adaptation.

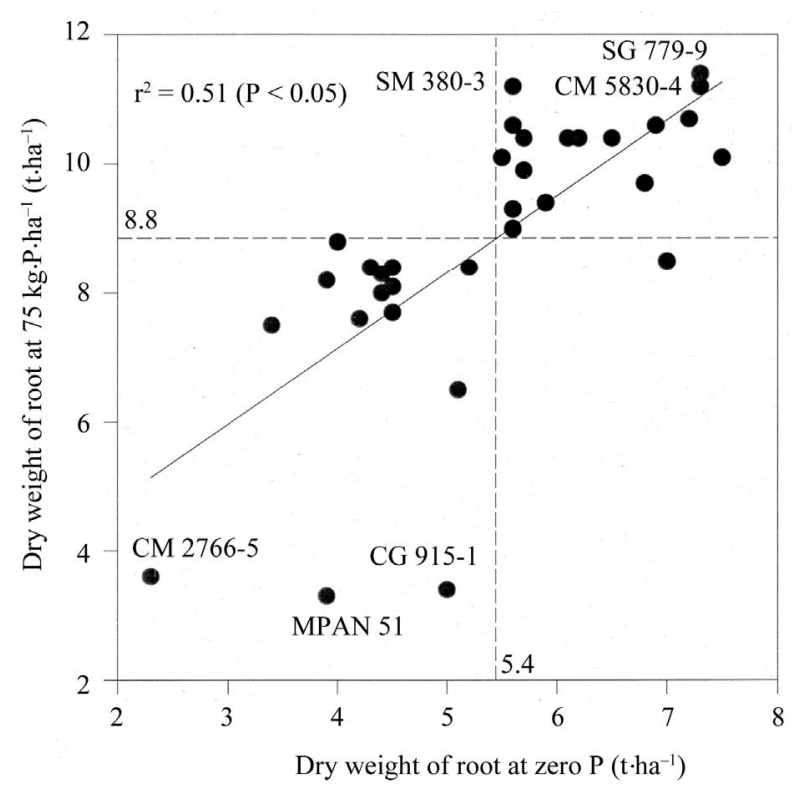

Figure 10. Relationship between dry root yield of 33 clones tested for three consecutive years at zero and $75 \mathrm{kgP} / \mathrm{ha}$ on the acidic clayey soils at Santander de Quilichao, Cauca, Colombia. Clones located within the right top quadrant were identified and selected for their high tolerance to Low$P$ as well as their response to $P$ application. Source: $M$. A. El-Sharkawy, unpublished. are highly to moderately tolerant. Two cultivars of Brazilian origin, i.e., M BRA 390 and M BRA 589, are tolerant to low-P soils, indicating the efficient selection under poor soils in Brazil. In previously tested group of accessions, another two Brazilian cultivars, M BRA 191 and M BRA383, were identified with high level of tolerance [35,78]. Table $10[75,78]$ presents plant traits, leaf gas exchange characteristics of upper canopy leaves, along with correlations of these traits with Low-P adaptation index, determined on another 33 accessions. At zero $\mathrm{P}, P_{N}$ was significantly higher than values at 75 $\mathrm{kg} / \mathrm{ha} \mathrm{P}$, and this coincided with increases in stomatal conductance to water vapor and in mesophyll conductance to $\mathrm{CO}_{2}$ diffusion, suggesting that the difference may be attributed to both stomatal behavior as well as to mesophyll biochemical and anatomical differences. Since LAI was significantly lower at zero $\mathrm{P}$, the higher $P_{N}$ could be partly due to less water stress resulting from lower transpiration water losses by crop canopy. Alternatively, the difference in $P_{N}$ may be also attributed to feedback inhibition at adequate $\mathrm{P}$ because of larger LAI, which represents greater crop photosynthetic surface capacity. It is likely, therefore, that source-sink relationship for photosynthetic products was implicated in this sort of phenomenon. Application of $\mathrm{P}$ increased significantly 
Table 10. Productivity, growth and physiological characteristics of cassava grown at low and adequate P levels at Santander de Quilichao, and correlation with Low-P adaptation index [75,78]. Values are means of 33 clones.

\begin{tabular}{|c|c|c|c|}
\hline Parameter & Zero P & $75 \mathrm{~kg} \mathrm{P} / \mathrm{ha}$ & $\begin{array}{l}\text { Correlation coefficients with } \\
\text { Low-P adaptation index }\end{array}$ \\
\hline$P_{N}\left(\mu \mathrm{mol} \cdot \mathrm{CO}_{2} \cdot \mathrm{m}^{-2} \cdot \mathrm{s}^{-1}\right)$ & $31 *$ & 27 & $0.51^{* *}$ \\
\hline $\begin{array}{l}\text { Stomatal conductance }\left(\mathrm{H}_{2} \mathrm{O}\right) \\
\quad\left(\mathrm{mmol} \cdot \mathrm{m}^{-2} \cdot \mathrm{s}^{-11}\right)\end{array}$ & 928 & 851 & $0.30 \mathrm{~ns}$ \\
\hline $\begin{array}{l}\text { Mesophyll conductance }\left(\mathrm{CO}_{2}\right), \\
\left(\mathrm{mmol} \cdot \mathrm{m}^{-2} \cdot \mathrm{s}^{-1}\right)\end{array}$ & 206 & 178 & $0.57 * *$ \\
\hline Dry root yield (t/ha) & $8.8^{*}$ & 12.5 & $0.99 * *$ \\
\hline Shoot dry biomass(t/ha) & $3.8^{*}$ & 5.7 & $0.58 * *$ \\
\hline Total biomass (t/ha) & $12.6^{*}$ & 18.2 & $0.96^{* *}$ \\
\hline Number of storage root/plant & $9 *$ & 12 & $0.67 * *$ \\
\hline $\operatorname{LAI}\left(\mathrm{m}^{2} \cdot \mathrm{m}^{-2}\right)$ & $2.0^{*}$ & 3.1 & $0.55 * *$ \\
\hline HI (dry root/total biomass) & $0.81 *$ & 0.70 & $0.73 * *$ \\
\hline
\end{tabular}

Mean of the two $\mathrm{P}$ levels across 33 clones; $\mathrm{ns}=$ not significant at $5 \%$; $=$ significant at $5 \%$; **= significant at $1 \%$.

number of storage roots per plant, shoot biomass and dry root yield, but HI was lower, compared to zero P. Except with stomatal conductance, Low-P adaptation index was highly significantly correlated with all of the growth and gas exchange traits measured, indicating the validity of this index as a measure for identifying plant traits related to productivity. It may be concluded that, carbon assimilation rates and sources (i.e. leaf $P_{N}$ and canopy seasonal LAI) as well as sink strength and capacity for photo-assimilates (storage root number and capacity) are of paramount importance as selectable traits for cassava improvement under diverse edaphic environmental conditions $[34,35,50,72,81]$.

\subsection{Performance of Some Cassava Clones at Zero and $100 \mathrm{kgK} / \mathrm{ha}$}

Figure 9 and several reports [70,79,80,82-86] have shown significant responses to $\mathrm{K}$ fertilizer in different soils, particularly when cassava was grown continuously for several years in the same field due to removal of large $\mathrm{K}$ amount $(>70 \%$ of extracted $\mathrm{K})$ in harvested storage roots. Moreover, research at CIAT $[79,80,87]$ have indicated the existence of genetic diversity in response to $\mathrm{K}$ application and in $\mathrm{K}$ use efficiency, which warranted further selection for tolerance to low-K soils.

Table 11 and Figure 11 present 5-year average data on oven-dried root yield at 10 months after planting 15 clones on acidic clayey soil at CIAT Santander de Quilichao Experimental Station, in response to zero and 100 $\mathrm{kg} \mathrm{K} / \mathrm{ha}$. In these trials, mean dry root yields at first year were 11.1 and $13.2 \mathrm{t} / \mathrm{ha}$ for zero and $100 \mathrm{~kg} \mathrm{~K} / \mathrm{ha}$, respectively. Response to $\mathrm{K}$ application was significant (LSD 5\% $=1.4 \mathrm{dry} \mathrm{t} / \mathrm{ha}$ ). At the fifth year of consecutive cropping, average yields across all clones had dropped to 3.7 and $7.3 \mathrm{t} / \mathrm{ha}$ for zero and $100 \mathrm{~kg} \mathrm{~K} / \mathrm{ha}$, respectively. The reduction in yield was so dramatic to the extent that application of $100 \mathrm{~kg} \mathrm{~K} / \mathrm{ha}$ had failed to sustain productivity that was obtained at the initial year of trial without $\mathrm{K}$ application. The reduction in yields were even greater in absence of $\mathrm{K}$ application (average yield dropped from 11.1 at the $1^{\text {st }}$ year to $3.7 \mathrm{t} / \mathrm{ha}$ at the $5^{\text {th }}$ year), indicating the large depletion of soil native K. Application of K at the $5^{\text {th }}$ year almost doubled the yield relative to value of unfertilized crops $(7.3 \mathrm{t} / \mathrm{ha}$ at $100 \mathrm{~kg} \mathrm{~K}$ as compared to $3.7 \mathrm{t} / \mathrm{ha}$ without $\mathrm{K}$ application). Removal of $\mathrm{K}$ by storage roots were $72 \%$ of total $\mathrm{K}$ uptake in both zero and $100 \mathrm{~kg}$ $\mathrm{K} / \mathrm{ha}$, which is in the range reported in previous trials $[79,80,87]$. Thus, in these soils potassium becomes the most limiting factor (see Figure 9) after several years of continuous cropping without sufficient fertilization to compensate for $\mathrm{K}$ removal in harvested roots. Because most cassava production is done by resource-poor smallholders $[4,5]$ in marginal lands low in native essential major nutrients, and mainly without application of fertilizers, genetic alleviation of such critical situation becomes of paramount importance. Selection and breeding for improved cultivars that tolerate low-K soils as well as possess high $\mathrm{K}$ use efficiency (i.e. higher yield/nutrient uptake) would benefit the poorest of the poor cassava farmers in the tropics. Such desired materials with high to moderate Low-K adaptation index were identified and selected as shown in Table 11 and Figure $\mathbf{1 1}$ and in $[79,80,87]$. Out of 15 accessions (all are CIAT breeding materials), there were 5 clones with high Low-K adaptation index (ranging from 1.5 to 2.2, relative to the overall trial mean of 1.0), 5 clones with moderate adaptation index (ranging from 1.2 to 1.4 ), and 5 clones with low adaptation index (ranging from 0.4 to 1.0). To illustrate the agronomic benefits of these selected materials, the estimated $\mathrm{K}$ use efficiency values, in terms of dry root produced per unit $\mathrm{K}$ uptake, were 260 and $180 \mathrm{~kg}$ dry root $/ \mathrm{kg} \mathrm{K}$ uptake at zero and $100 \mathrm{~kg} \mathrm{~K} / \mathrm{ha}$, respectively, 
Table 11. Dry root yield (Y, t/ha, average of 5 years) of cassava as affected by potassium application, and Low-K adaptation index for some cassava clones. Source: M. A. El-Sharkawy, unpublished.

\begin{tabular}{|c|c|c|c|}
\hline Clone & $0 \mathrm{~kg} \mathrm{~K} / \mathrm{ha}$ & $\begin{array}{ll} & 100 \mathrm{~kg} \mathrm{~K} / \mathrm{ha} \\
\text { Y Y } & \end{array}$ & Low-K adaptation index ${ }^{a}$ \\
\hline CM 4777-2 & 8.7 & 13.5 & $2.2 \mathrm{HA}^{\mathrm{b}}$ \\
\hline CG 402-11 ${ }^{*}$ & 8.7 & 12.6 & $2.0 \mathrm{HA}$ \\
\hline $\mathrm{CM} 4574-7$ & 7.6 & 12.7 & $1.8 \mathrm{HA}$ \\
\hline CM 5286-3 & 7.6 & 10.5 & $1.5 \mathrm{HA}$ \\
\hline CG 165-7 & 6.3 & 10.8 & $1.5 \mathrm{HA}$ \\
\hline CM 4729-4 & 7.8 & 9.5 & $1.4 \mathrm{MA}^{\mathrm{c}}$ \\
\hline CG 1141-1 & 6.7 & 10.2 & $1.3 \mathrm{MA}$ \\
\hline CM 2777-2 & 6.1 & 11.2 & $1.3 \mathrm{MA}$ \\
\hline CM 3372-4 & 6.1 & 10.7 & $1.2 \mathrm{MA}$ \\
\hline CM 3306-4 & 5.8 & 10.4 & $1.2 \mathrm{MA}$ \\
\hline CM 3311-3 & 6.3 & 8.9 & $1.0 \mathrm{LA}^{\mathrm{d}}$ \\
\hline SG 107-35 & 6.1 & 8.9 & $1.0 \mathrm{LA}$ \\
\hline CM 2766-5 & 5.8 & 8.6 & $0.9 \mathrm{LA}$ \\
\hline CM 2177-2 & 5.2 & 7.3 & $0.7 \mathrm{LA}$ \\
\hline CM 3299-4 & 3.6 & 5.5 & $0.4 \mathrm{LA}$ \\
\hline Mean of trial (15 clones) & 6.6 & 10.1 & 1.0 \\
\hline LSD $5 \%$ for clones & 1.1 & 1.2 & \\
\hline LSD $5 \%$ for $\mathrm{K}$ level & 0.4 & & \\
\hline
\end{tabular}

${ }^{*} \mathrm{CG} 402-11$, is the tallest and greatest shoot biomass, compared to the rest of accessions.

${ }^{\mathrm{a}}$ Low-K adaptation index $=\frac{(\text { Dry root yield at zero } \mathrm{K})(\text { Dry root yield at } 75 \mathrm{~kg} \mathrm{~K} / \mathrm{ha})}{(\text { Mean clones dry root yield at zero } \mathrm{K})(\text { Mean clones dry root yield at } 75 \mathrm{~kg} \mathrm{~K} / \mathrm{ha})} ;{ }^{\mathrm{b}} \mathrm{HA}=$ High adaptation; ${ }^{\mathrm{c}} \mathrm{MA}=\mathrm{Moderate}$ adaptation; ${ }^{\mathrm{d}} \mathrm{LA}=\mathrm{Low}$ adaptation.

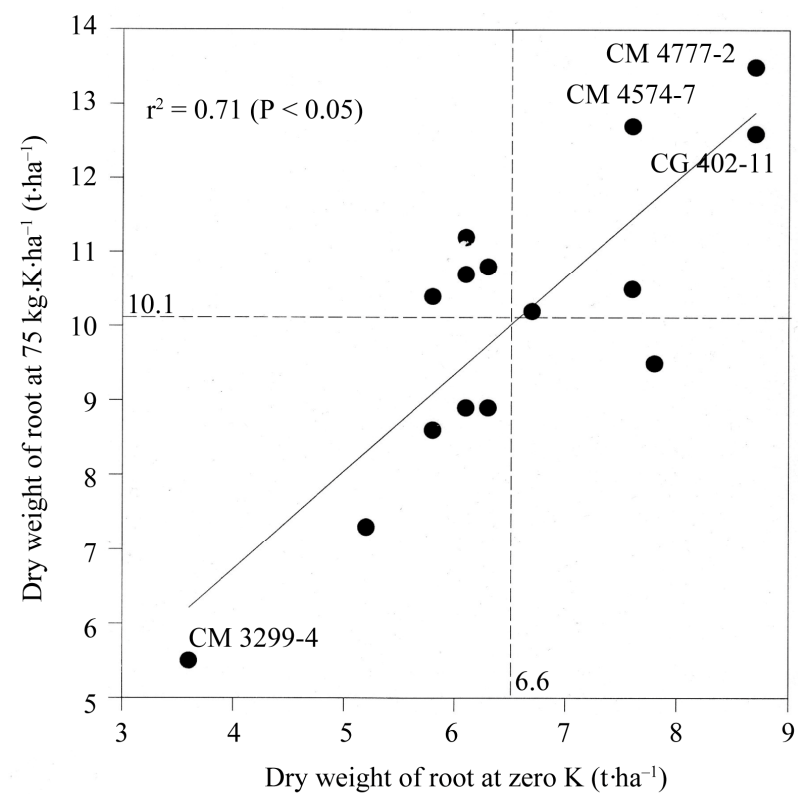

Figure 11. Relationship between dry root yield of 15 clones tested for five consecutive years at zero and $100 \mathrm{~kg} \mathrm{~K} / \mathrm{ha}$ on the acidic clayey soils at Santander de Quilichao, Cauca, Colombia. Clones located within the right top quadrant were identified and selected for their high tolerance to Low$K$ as well as their response to $K$ application. Source: $M$. A. El-Sharkawy, unpublished. in Clone $\mathrm{CM}$ 4777-2 showing the highest $\mathrm{K}$ adaptation index (of 2.2). On the other hand, in clone CM 3299-4 showing the lowest $\mathrm{K}$ adaptation index (of 0.4 ), the $\mathrm{K}$ use efficiency values were 193 and $140 \mathrm{~kg}$ dry root $/ \mathrm{kgK}$ uptake at zero and $100 \mathrm{~kg} \mathrm{~K} / \mathrm{ha}$, respectively.

In this group of clones, all, except CG 402-11, are short-to-medium stature $(<2.0 \mathrm{~m})$ with low shoot biomass and high HI. CG 402-11with the second highest adaptation index of 2.0 , has the tallest stature $(>2.0 \mathrm{~m})$, largest shoot biomass $(7.2$ and $9.8 \mathrm{t} /$ ha at zero and $100 \mathrm{~kg}$ $\mathrm{K} /$ ha, respectively, compared with the respective trial mean values of 2.9 and 4.1 ), the greatest total $\mathrm{K}$ uptake, of which $45 \%-47 \%$ in shoot 68 at zero $\mathrm{K}$ and $91 \mathrm{~kg}$ $\mathrm{K} / \mathrm{ha}$ at $100 \mathrm{~kg} \mathrm{~K}$, compared with the respective trial mean values of 44 and $80 \mathrm{~kg} \mathrm{~K} / \mathrm{ha}$ ), and the least $\mathrm{K}$ use efficiency $(158 \mathrm{~kg}$ dry root $/ \mathrm{kg} \mathrm{K}$ at zero $\mathrm{K}$ and 128 at $100 \mathrm{~kg} \mathrm{~K}$, compared to the overall respective trial mean values of 210 and $148 \mathrm{~kg}$ dry root $/ \mathrm{kg} \mathrm{K}$ ). These findings substantiate data in Table 5, and support the strategy for selecting short-to-medium cultivars in order to alleviate pressure on soil fertility without sacrificing root yield [42, $60]$. It may be concluded that the calculated adaption index, as defined here, is a reliable agronomic indicator for screening large number of accessions under field conditions. Coupled with this adaptation index, it is recommended to determine nutrient uptake for estimating 
nutrient use efficiency.

\section{Selection for Photosynthesis in Relation to Productivity under Prolonged Drought Coupled with High Temperatures in Seasonally Dry and Semiarid Environments}

\subsection{Rational}

Current hydrological and GCMs models [66-88] predict, within the next decades, the occurrence of extended drought periods across continents, coupled with irregularity in intensity and distribution of rainfall, as well as a possible increase in land area prone to drought in tropical and subtropical regions. This expected shortage in water resources, combined with rises in Earth's surface temperature, will be significant enough to negatively impacts agricultural productivity and food security for the projected $>9$ billion world population [67,89-93], particularly in developing countries. The inherent capacity of cassava to tolerate adverse environments, a comparative advantage over most tropical staple food crops, enhanced the expansion of the crop cultivation in more marginal areas in sub-Saharan Africa, Northeastern Brazil and other areas in Asia $[4,54,94]$. Moreover, in the coming decades when experiencing globally warming climate, cassava will play even more important role, as other less adapted staple food crops will probably fail to produce reasonably [45,54,95], (see Figures 2 and 3). Cassava responds positively to elevated $\mathrm{CO}_{2}$ [46-48] (see Figure 5), and to high temperatures [42] (see Figure 4), two crucial atmospheric characteristics of climate change. Adaptation and mitigation measures then become essential approaches to obviate expected adverse effects of climate change $[66,96]$, with the development of improved genetic and agronomic technologies being the main elements. The CIAT's cassava research took the initiative to contribute to such approach.

\subsection{Photosynthesis and Yield Performances in Seasonally Dry and Semiarid Environments in Northern Coast of Colombia}

Field trials were conducted on private farms at two representative dry locations in northern Colombia [97]. The seasonally dry site (at Santo Tomas, Atlantic; elevation $14 \mathrm{~m}$; latitude $10^{\circ} 57^{\prime} \mathrm{N}$; longitude $74^{\circ} 47^{\prime} \mathrm{W}$, and characterized by: $<900 \mathrm{~mm}$ of rainfall in 7 months; annual pan evaporation of $1650 \mathrm{~mm}$; mean temperature of $28^{\circ} \mathrm{C}$; annual solar radiation of $6752 \mathrm{MJ} \cdot \mathrm{m}^{-2}$; extended dry season of 4 - 5 months; sandy infertile soils, $>80 \%$ sand). The semiarid site (at Riohacha, Guajira; elevation $4 \mathrm{~m}$; latitude $11^{\circ} 32^{\prime} \mathrm{N}$; longitude $72^{\circ} 56^{\prime} \mathrm{W}$, and characterized by: $<600 \mathrm{~mm}$ of rainfall in 7 months, $64 \%$ occurred in 3 months; annual pan evaporation of $2293 \mathrm{~mm}$; mean tem- perature of $28^{\circ} \mathrm{C}$; annual solar radiation of 6816 of $\mathrm{MJ} \cdot \mathrm{m}^{-2}$; extended dry period $>5$ months; sandy infertile soils, $>80 \%$ sand). No chemical fertilizers nor irrigation were applied in both trials. Two groups of CIAT breeding lines and cultivars originating in Brazil, Colombia and Venezuela were evaluated for their upper canopy $P_{\mathrm{N}}$, measured by portable infrared gas analyzers on several occasions during dry periods on 4 - 5 months after planting, and yields were determined at 11 months after planting.

Table 12 presents data on yield and leaf gas exchange at both environments. At the seasonally dry environment, upper canopy $P_{N}$ ranged from 25 to $31 \mu \mathrm{mol} \cdot \mathrm{CO}_{2} \cdot \mathrm{m}^{-2} \cdot \mathrm{s}^{-1}$ among cultivars, whereas at the semiarid environment $P_{N}$ ranged from 7 to $20 \mu \mathrm{mol} \cdot \mathrm{CO}_{2} \cdot \mathrm{m}^{-2} \cdot \mathrm{s}^{-1}$, with cultivars significant differences. Both stomatal conductance and intercellular $\mathrm{CO}_{2}$ varied significantly among cultivars. Average values of leaf gas exchange were much greater in the seasonally dry environment, indicating the pronounced effect of drought in semiarid environment where variations among cultivars were wider. The top ranking clones CG 1141-1 at seasonally dry location and CM 4013-1 at semiarid location, both are CIAT breeding materials. Local varieties, i.e. M Col 1505 and M Col 2215, were also within the top ranks, indicating their adaptability to these environments. The short-stemmed M Col 2215 was tested earlier in the seasonally dry Patia Valley, Cauca, and was identified for its tolerance to drought, high dry matter content in storage root $(>40 \%)$, better leaf retention, high $P_{N}$ and elevated PEPC activity $[37,43]$. Therefore, it was introduced to Ecuador in late 1980's for testing in the semiarid western coast (rainfall $<600 \mathrm{~mm}$ in 4 months), and was officially released in 1992 under the local name "Portoviejo 650", after farmers participation in its evaluation for three years in various locations [44].

Oven-dried storage root yields varied significantly among cultivars in the two environments, ranging from 0.65 to $0.76 \mathrm{~kg} / \mathrm{m}^{2}$ in the seasonally dry, and from 0.04 to $0.33 \mathrm{~kg} / \mathrm{m}^{2}$ in the semiarid, with the overall mean of the former $\left(0.67 \mathrm{~kg} / \mathrm{m}^{2}\right)$ was more than double that in the later $\left(0.23 \mathrm{~kg} / \mathrm{m}^{2}\right)$. Such productivity in these harsh environments attests to the remarkable potential of cassava and its resilience and tolerance to extreme environmental conditions, both edaphic and climatic.

Yield in both environments was highly significantly correlated with seasonal average upper canopy leaf $P_{N}$ (Figure 12), indicating the importance of selection for higher photosynthetic capacity in relation to productivity in these environments. The relation was due more to nonstomatal effects (such as mesophyll anatomy and biochemical components of carbon fixation pathway), since yield was significantly negatively correlated with the intercellular $\mathrm{CO}_{2}\left(C_{\mathrm{i}}\right)$ (Figure 13). In other trials, at the 
Table 12. Average net photosynthetic rate, $P_{N}\left(\mu \mathrm{mol} \cdot\left(\mathrm{CO}_{2}\right) \cdot \mathrm{m}^{-2} \cdot \mathrm{s}^{-1}\right)$, stomatal conductance, $\mathrm{g}_{\mathrm{s}}\left(\mathrm{mol} \cdot\left(\mathrm{H}_{2} \mathrm{O}\right) \cdot \mathrm{m}^{-2} \cdot \mathrm{s}^{-1}\right)$, intercellular $\mathrm{CO}_{2}$ concentration, $C_{\mathrm{i}}(\mu \mathrm{mol} / \mathrm{mol})$ and dry root yield $\left(\mathrm{kg} / \mathrm{m}^{2}\right)$ of field-grown cassava under rain-fed conditions at Santo Tomás, Atlantic Department (seasonally dry environment) and Riohacha, Guajira (semi-arid environment) [97].

\begin{tabular}{|c|c|c|c|c|}
\hline Locality and cultivar & Dry root yield & $P_{N}$ & $g_{s}$ & $c_{i}$ \\
\hline \multicolumn{5}{|l|}{ Santo Tomás } \\
\hline CG 1141-1 & 0.76 & 31 & 0.38 & 179 \\
\hline SG 536-1 & 0.72 & 29 & 0.39 & 234 \\
\hline MCol 1505 & 0.60 & 29 & 0.43 & 215 \\
\hline CM 3306-4 & 0.74 & 28 & 0.38 & 195 \\
\hline MBra 191 & 0.65 & 27 & 0.38 & 196 \\
\hline CM 4013-1 & 0.72 & 26 & 0.38 & 224 \\
\hline MBra 12 & 0.70 & 25 & 0.36 & 196 \\
\hline CM 3555-6 & 0.58 & 25 & 0.37 & 243 \\
\hline CM 4063-6 & 0.62 & 25 & 0.37 & 207 \\
\hline MCol 2215 & 0.65 & 25 & 0.44 & 209 \\
\hline Mean of all cultivars & 0.67 & 27 & 0.38 & 209 \\
\hline $\operatorname{LSD}(0.05)$ & 0.15 & 3.5 & 0.064 & 35 \\
\hline \multicolumn{5}{|l|}{ Riohacha } \\
\hline CM 4013-1 & 0.33 & 20 & 0.46 & 271 \\
\hline MCol 2215 & 0.30 & 20 & 0.47 & 233 \\
\hline MCol 1505 & 0.23 & 15 & 0.49 & 295 \\
\hline MCol 1734 & 0.32 & 15 & 0.43 & 257 \\
\hline CG 1141-1 & 0.28 & 13 & 0.44 & 281 \\
\hline MCol 1684 & 0.23 & 13 & 0.47 & 295 \\
\hline SG 536-1 & 0.26 & 12 & 0.44 & 341 \\
\hline CM 4063-6 & 0.32 & 12 & 0.45 & 305 \\
\hline MCol 1468 & 0.18 & 9 & 0.47 & 310 \\
\hline MCol 22 & 0.20 & 8 & 0.50 & 312 \\
\hline MBra 12 & 0.12 & 7 & 0.59 & 330 \\
\hline CM 3306-4 & 0.22 & 7 & 0.42 & 310 \\
\hline MVen 77 & 0.04 & 7 & 0.37 & 307 \\
\hline Mean of all cultivars & 0.23 & 12 & 0.46 & 295 \\
\hline $\operatorname{LSD}(0.05)$ & 0.08 & 3.8 & 0.096 & 58 \\
\hline
\end{tabular}

seasonally dry environment in Patia Valley, Cauca, yield was significantly correlated with $P_{N}, \mathrm{C}_{4}$ PEPC enzyme, mesophyll conductance to $\mathrm{CO}_{2}$ diffusion, and PNUE (see Table 1, and Figure 1). These characteristics are related to biochemical/anatomical components of leaf photosynthesis and point to the importance of PEPC as a selection criteria in dry environments $[35,42,43]$.

\subsection{Breeding for Drought Tolerance in the Semiarid Northeastern Brazil}

The physiological research at CIAT have elucidated and documented the many mechanisms underlying cassava tolerance to abiotic stresses $[4,35,42]$, and was pivotal in enhancing interests for expanding cassava production in semiarid areas in South America and Sub-Saharan Africa, areas where other main staple tropical crops such as cereals and grain legumes probably will fail to produce. In 1991, the Brazilian national (CNPMF) and state research institutions in coordination with CIAT, had initiated a 5 -year project for breeding cassava in drier tropics and subtropics with funds from the International Fund For Agriculture Development (IFAD) $[4,98,99]$. Cassava germplasm (500 clones) from northeastern Brazil and the north coast of Colombia was initially screened at four semiarid sites in northeastern Brazil, characterized by extended drought for several months, hot weather, and sandy infertile soils with presence of pests and diseases [4]. Some accessions were selected for their broad adap- 


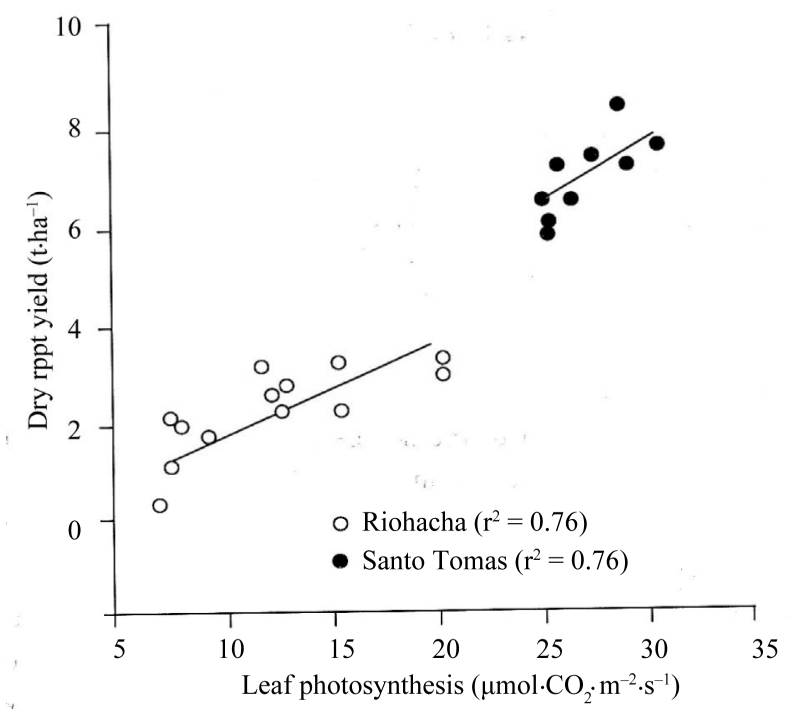

Figure 12. Relationships between root yield and leaf photosynthesis of several cassava clones grown in seasonally dry (Santo Tomás, Atlantico) and semiarid (Riohacha, Guajira) environments $[80]$.

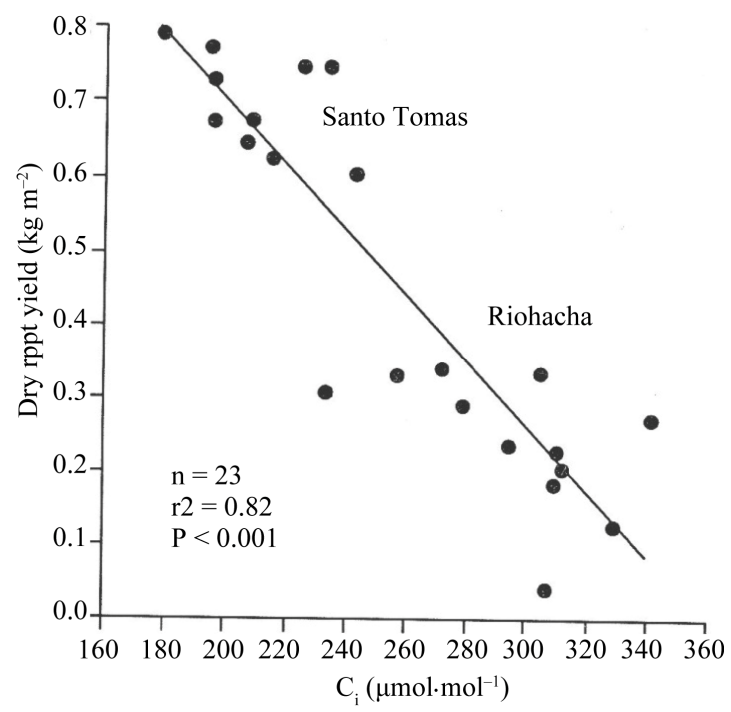

Figure 13. Relationship between dry root yield and intercellular $\mathrm{CO}_{2}$ concentration $\left(C_{\mathrm{i}}\right)$ for two groups of cassava cultivars grown under rain-fed conditions at Riohacha (semi-arid) and Santo Tomás (seasonally dry). The $C_{\mathrm{i}}$ values were calculated from leaf gas fluxes via standard Gaastra equations: the higher photosynthetic rates, the lower $C_{\mathrm{i}}$ values. Regression equation: yield $=1.52-0.004 C_{\mathrm{i}} ; \mathrm{r}^{2}=$ $0.82(P<0.001)$ [97]. This relation indicates that yield differences among cultivars are related mostly to differences in leaf mesophyll characteristics (i.e. anatomical and biochemical factors).

tation across sites to contribute in a recombination and selection program (Table 13). Yields of selected clones at 12 months and 18 months after planting demonstrate the high potential of cassava in these drier areas. Also, some progenies, via hybridization, have been developed and sent to ITTA, Nigeria, for adaptation and selection under drier areas in sub-Saharan Africa [100]. Farmers had participated in evaluating and selecting adapted materials that resulted in rapid acceptance and, consequently, in the release of several improved clones [101].

\section{Conclusions and Future Research}

The research reviewed here on cassava productivity, ecophysiology, breeding, and responses to environmental stresses was conducted in collaboration with a multidisciplinary team at CIAT. Under favorable environments in lowland and mid-altitude tropical zones with near-optimal climatic and edaphic conditions for the crop to realize its inherent potential, cassava is highly productive in terms of root yield and total biological biomass, conferring a competitive advantage over other tropical energy crops. Under stressful environments with extended drought of several months and low-fertility soils, where major cereal and legume crops might fail, cassava produces reasonably well. This inherent capacity to tolerate complex stresses is supported by several morphological, physiological and biochemical mechanisms and traits, such as long leaf life, tight stomatal control over gas exchange, high photosynthetic potential and extensive fine root systems. Core germplasm was characterized and several clones tolerant to water stress and low-fertility soils were identified to breed for drier areas in Africa and Latin America. Selection for nutrient use efficient shortto-medium cassava was found to be advantageous for soil fertility conservation while retaining yield potential.

Modeling predicts the suitability of cassava in globally warming climate versus other food crops, confirming its high level of tolerance [45]. Cassava has high optimum temperature for photosynthesis and growth, and responds positively to elevated $\mathrm{CO}_{2}$ that point to its potential as food, feed and energy crop in tropical and subtropical zones adversely affected by climate changes. Because of its high costs using sophisticated methodology, currentclimate research is still confined within developed temperate zones $[46,66,68,102]$. Yet, there is an urgent need to conduct climate research in representative tropical ecosystems where GCMss cenarios predict the worst consequences for agricultural productivity and food security $[66,67,92,93]$. The use of the Free Air $\mathrm{CO}_{2}$ Enrichment (FACE) technology in combination with rain shelters which facilitates evaluating interactions of $\mathrm{CO}_{2}$ with soil water status $[68,103]$, may further enhance developing improved cassava cultivars adapted to increasing atmospheric $\mathrm{CO}_{2}$. Moreover, temperature influences may be studied under field conditions using the "Temperature Free-Air Controlled Enhancement (T-FACE)" technique, as was recently described and used at U.S. Arid-Land Agricultural Research Center, USDA, Maricopa, Arizona [104]. Developed countries, who are the 
Table 13. Clones [(harvested at 12 and 18 months $(M)]$ with good level of adaptation at the semiarid screening site in Quixadá, Ceará, northeastern Brazil, 1996.Source: (CIAT/CNPMF breeding database, 1996, unpublished).

\begin{tabular}{|c|c|c|c|c|c|c|}
\hline \multirow[t]{2}{*}{ Brazil accession code } & \multicolumn{2}{|c|}{ Fresh root yield $\left(\mathrm{t} \cdot \mathrm{ha}^{-1}\right)$} & \multicolumn{2}{|c|}{ Dry root yield $\left(\mathrm{t} \cdot \mathrm{ha}^{-1}\right)$} & \multicolumn{2}{|c|}{ Dry matter content in roots $(\%)$} \\
\hline & $12 \mathrm{M}$ & $18 \mathrm{M}$ & $12 \mathrm{M}$ & $18 \mathrm{M}$ & $12 \mathrm{M}$ & $18 \mathrm{M}$ \\
\hline BGM 649 & 14.9 & 32.0 & 4.7 & 11.5 & 31.8 & 35.7 \\
\hline BGM 651 & 10.7 & 30.2 & 3.2 & 10.0 & 29.9 & 33.2 \\
\hline BGM 814 & 10.2 & 36.1 & 2.5 & 13.7 & 24.1 & 37.8 \\
\hline BGM 834 & 23.8 & 39.8 & 5.7 & 12.7 & 24.2 & 31.8 \\
\hline BGM 867 & 11.8 & 32.2 & 2.8 & 11.5 & 23.4 & 36.0 \\
\hline BGM 876 & 14.6 & 38.0 & 3.6 & 13.7 & 24.5 & 36.1 \\
\hline BGM 924 & 13.5 & 37.0 & 2.3 & 12.5 & 17.3 & 33.7 \\
\hline Mean of selections & 14.2 & 35.0 & 3.5 & 12.2 & 25.0 & 34.9 \\
\hline Trial mean & 12.7 & 26.6 & 3.2 & 9.2 & 25.2 & 34.5 \\
\hline Check varieties & 7.1 & 27.8 & 1.7 & 9.8 & 23.8 & 35.3 \\
\hline
\end{tabular}

Note: Farmers participated in the evaluation process and selected three clones with high yield and high dry matter content, and multiplied their planting materials even before being officially released. Farmers' participation was crucial in enhancing the selection process and in speeding up adoption and diffusion of improved technology. The large increases in yield and in dry matter content at 18 months were attributed to the rainfall received in the last six months. At Quixadá, long-term mean annual rainfall is less than $700 \mathrm{~mm}, 80 \%$ falling mostly in $3-4$ months and the rest of the year is dry coupled with hot climate that renders effective rainfall for growth to be less than $500 \mathrm{~mm}$ (total annual radiation $=8130 \mathrm{MJ} \cdot \mathrm{m}^{-2}$, mean annual temperature $=27^{\circ} \mathrm{C}$, potential annual evapotranspiration $=2369 \mathrm{~mm})$ [4]. The soil at this site is sandy $(>80 \%$ sand) with low water holding capacity. Clones such as BGM 649 , BGM 651 , BGM 834 and BGM 876 had yields ranging between 3.2 to 5.7 dry $\mathrm{t} \cdot \mathrm{ha}^{-1}$ at 12 months, compared to $1.7 \mathrm{t} \cdot \mathrm{ha}^{-1}$ of local checks. In semiarid environments such improved germplasm is crucial for food security where staple grain crops will probably fail to produce reasonable yields.

main polluters of the atmosphere, via excessive carbon emissions, must shoulder the costs of climate research in tropical and subtropical regions. Oil-rich Arabian/Persian Gulf States should take the lead in supporting developing countries to cope with-and-adapt-to consequences of warming climate.

Molecular biology technology is also needed with focus on applications into crop improvement. For example, this technology is useful for genetically transferring simple qualitative traits controlled by one or two genes, as already had been demonstrated by the successful production and use of insect-resistant transgenic commercial crop cultivars containing the soil bacterium, Bacillus thuringiensis $(\mathrm{Bt})$ genes that produce the toxic Cry proteins. In contrast, quantitative multigenic traits such as tolerance/resistance to compound abiotic-stresses are unlikely to be easily amenable to genetic engineering via inserting few exotic genes. These traits when expressed at the whole organism level are mostly attributed to a range of morphological, anatomical, physiological and biochemical characteristics and mechanisms. So far, modest advances at the experimental levels were recently reported for the use of genetic molecular markers in cassava selection and breeding efforts for developing drought-tolerant cultivars [105]. Transgenic approaches for improving water stress tolerance and leaf retention were also considered [106,107]. Genetic modifications through the use of the modern recombinant DNA technology may play an important role in improvement of the crop only when it complements and integrates with other fields of science and not done in isolation $[53,108]$.
Moreover, to be cost-effective, the technology outputs must be tested and evaluated in whole-plant and within relevant cropping systems under prevailing environments as well as under predicted climatic changes in the $21^{\text {st }}$ century [66-68,109].

Connor et al., in their recently revised Crop Ecology text book [109, see page 269 of the book], have rightly commented on the current research efforts targeted towards genetically transferring the quite complex $\mathrm{C}_{4}$ photosynthetic syndrome to $\mathrm{C}_{3}$ rice, where significant financial support was recently devoted to, by saying: "What a pity that cassava does not share the world-food limelight with rice. This species has the most, and best studied, intermediate photosynthetic types, and beneficial growth and yield responses have been demonstrated in them (Section 10.1.2). The pathway to success ought to be shorter for this crop. It would be exciting to see progress in the search for this current 'holy grail' of biotechnology during the lifetime of this book." Quote. Research institutions and donors agencies concerned with agricultural research and development must be aware of the high potential of cassava as food, feed, and industrial crop and its role in the face of global climate change.

\section{Acknowledgements}

The author wishes to express his gratitude to Colombian farmers for their hospitality during conducting some of this research. Without the collaboration of the many former field laborers, secretaries, research associates, students and colleagues, who are now dispersed across 
countries, the achievements highlighted here would have never been obtained. The invaluable courtesy copies of books documenting important research on crop ecology by David Connor, Robert Loomis and Kenneth Cassman, and on climate change by Mary Beth Kirkham, and Cynthia Rosenzweig, article reprints from Andy Jarvis, Julian Ramirez-Villegas and David Rosenthal were appreciated. I am grateful for the waiving of the required pagecharges by the Editors of OJSS. Constructive comments from anonymous reviewers were received. Thanks to Farah El-Sharkawy Navarro for the editorial and the WWWnet search assistance.

\section{REFERENCES}

[1] IFAD and FAO, "The World Cassava Economy, Facts, Trends and Outlook," International Fund for Agricultural Development and Food and Agriculture Organization of the United Nations, Rome, 2000.

http://www.scribd.com/doc/48938803/The-world-cassava -economy-I

[2] A. C. Allem, "The Origin and Taxonomy of Cassava," In: R. J. Hillocks, J. M. Thresh and A. C. Bellotti, Eds., Cassava: Biology, Production and Utilization, CABI Publishing, New York, 2002, pp. 1-16. doi:10.1079/9780851995243.0001

[3] D. Ugent, S. Pozorski and T. Pozorski, "Archaelogical Manioc (Manihot) from Coastal Peru," Economic Botany, Vol. 40, No. 1, 1986, pp. 78-102. doi:10.1007/BF02858949

[4] M. A. El-Sharkawy, "Drought-tolerant Cassava for Africa, Asia, and Latin America," Bioscience, Vol. 43, No. 7, 1993, pp. 441-451. doi:10.2307/1311903

[5] A. M. Fermont,"Cassava and Soil Fertility in Intensifying Smallholder Farming Systems of East Africa," Ph.D. Thesis, Wageningen Agricultural University, Wageningen, The Netherlands, 2009.

[6] J. H. Cock, "Cassava: New Potential for a Neglected Crop," Westview Press, Boulder and London, 1985.

[7] H. H. Yeoh and V. D. Truong, "Protein Contents, Amino Acid Compositions and Nitrogen-to-Protein Conversion Factors for Cassava Roots," Journal of the Science of Food and Agriculture, Vol. 70, No. 1, 1996, pp. 51-54. doi:10.1002/(SICI)1097-0010(199601)70:1<51::AID-JSF A463>3.0.CO;2-W

[8] H. H. Yeoh and M. Y. Chew, "Protein Content and Amino Acid Composition of Cassava Leaf," Phytochemistry, Vol. 15, No. 11, 1976, pp. 1597-1599. doi:10.1016/S0031-9422(00)97435-1

[9] P. A. Lancaster and J. E. Brooks, "Cassava Leaves as Human Food," Economic Botany, Vol. 37, No. 3, 1983, pp. 331-348. doi:10.1007/BF02858890

[10] J. A. Montagnac, C. R. Davis and S. A. Tanumihardjo, "Nutritional Value of Cassava for Use as Staple Food and Recent Advances for Improvement," Composite Review in Food Science and Food Safety, Vol. 8, No. 3, 2009, pp. 181-194. doi:10.1111/j.1541-4337.2009.00077.x
[11] V. N. Djuikwo, R. A. Ejoh, I. Gouado, C. M. Mbofung and S. A. Tanumihardjo, "Determination of Major Carotenoids in Processed Tropical Leafy Vegetables Indigenous to Africa," Food and Nutrition Sciences, Vol. 2, No. 8, 2011, pp. 793-802. doi:10.4236/fns.2011.28109

[12] A. J. A. Essers, "Removal of Cyanogens from Cassava Roots: Studies on Domestic Sun-Drying and Solid-Substrate Fermentation in Rural Africa," Ph.D. Thesis, Wageningen Agricultural University, Wageningen, The Netherlands, 1995.

[13] J. Cliff, H. Muquingue, D. Nhassico, H. Nzwalo and J. H. Bradbury, "Konzo and Continuing Cyanide Intoxication from Cassava in Mozambique," Food and Chemical Toxicology, Vol. 49, No. 3, 2011, pp. 631-635. doi:10.1016/i.fct.2010.06.056 http://fws.aber.ac.uk/rec/CLIKAC.

[14] T. Tylleskar, "The Association between Cassava and the Paralytic Disease Konzo," Acta Horticulturae, Vol. 375, 1994, pp. 321-331.

[15] T. Tylleskar, M. Banea, N. Bikangi, R. D. Cooke, N. H. Poulter and H. Rosling, "Cassava Cyanogens and Konzo, an Upper Motor Neuron Disease in Africa," The Lancet, Vol. 339, No. 8787, 1992, pp. 208-211. doi:10.1016/0140-6736(92)90006-O

[16] V. Ravindran, "Cassava Leaves as Animal Feed: Potential and Limitations," Journal of the Science of Food and Agriculture, Vol. 61, No. 2, 1993, pp. 141-150. doi:10.1002/isfa.2740610202

[17] J.L Gil and A. J. A. Buitrago, "La Yuca en la Alimentacion Animal," In: B. Ospina, H. Ceballos, Eds., La Yuca en el Tercer Milenio: Sistemas Modernos de Produccion, Procesamiento, Utilizacion y Comercialización, Centro Internacional de Agricultura Tropical (CIAT), Cali, Colombia, 2002, pp. 527-569. http://www.clayuca.org/PDF/libro_yuca/capitulo28.pdf

[18] C. Balagopalan, "Cassava Utilization in Food, Feed and Industry," In: R. J. Hillocks, J. M. Thresh and A. C. Bellotti, Eds., Cassava: Biology, Production and Utilization, CABI Publishing, New York, 2002, pp. 301-318. doi:10.1079/9780851995243.0301

[19] B. A. Keating, G. L. Wilson and J. P. Evenson, "Effects of Length, Thickness, Orientation, and Planting density of Cassava (Manihot esculenta Crantz) Planting Material on Subsequent Establishment, Growth, and Yield," East Africa Agriculture and Forest Journal, Vol. 53, 1988, pp. 145-149.

[20] D. Leihner, “Agronomy and Cropping Systems," In: R. J. Hillocks, J. M. Thresh and A. C. Bellotti, Eds., Cassava: Biology, Production and Utilization, CABI Publishing, New York, 2002, pp. 91-113. doi:10.1079/9780851995243.0091

[21] C.Iglesias, C. Hershey, F. Calle and A. Bolaños, "Propagating Cassava (Manihot esculenta) by Sexual Seed," Experimental Agriculture, Vol. 30, No. 3, 1994, pp. 283290. doi:10.1017/S0014479700024388

[22] Q. E. A. van Oirschot, G. M. O’Brian, D. Dufour, M. A. El-Sharkawy and E. Mesa, "The Effect of Pre-harvest Pruning of Cassava upon Root Deterioration and Quality Characteristics," Journal of the Science of Food and Ag- 
riculture, Vol. 80 , No. 13, 2000, pp. 1866-1873. doi:10.1002/1097-0010(200010)80:13<1866::AID-JSFA7 $\underline{18>3.0 . \mathrm{CO} ; 2-\mathrm{H}}$

[23] World Bank, "Agricultural Research," World Bank, Washington DC, 1981.

[24] S. Wortman, "Beyond the Bottom Line," The Rockefeller Foundation, New York, 1981.

[25] R. J. Hillocks, J. M. Thresh and A. C. Bellotti, Eds., "Cassava: Biology, Production and Utilization," CABI Publishing, New York, 2002.

[26] K. Kawano, "Thirty Years of Cassava Breeding for Productivity-Biological and Social Factors for Success," Crop Science, Vol. 43, No. 4, 2003, pp. 1325-1335. doi:10.2135/cropsci2003.1325

[27] N. M. A. Nassar and A. R. Ortiz, "Cassava Improvement: Challenges and Impacts," Journal of Agricultural Science, Vol. 145, No. 2, 2007, pp. 163-171. doi:10.1017/S0021859606006575

[28] K.Kawano, P. Daza, A. Amaya A, M. Rios and W. M. F. Gonçalves, "Evaluation of Cassava Germplasm for Productivity," Crop Science, Vol. 18, No. 3, 1978, pp. 377382. doi:10.2135/cropsci1978.0011183X001800030006x

[29] J. H. Cock, D. Franklin, G. Sandoval and P. Juri, "The Ideal Cassava Plant for Maximum Yield," Crop Science, Vol. 19, No. 2, 1979, pp. 271-279. doi:10.2135/cropsci1979.0011183X001900020025x

[30] K. Kawano, "Harvest Index and Evolution of Major Food Crop Cultivars in the Tropics," Euphytica, Vol. 46, No. 3, 1990, pp. 195-202. doi:10.1007/BF00027218

[31] C. H. Hershey and D. L. Jennings, "Progress in Breeding Cassava for Adaptation to Stress," Plant Breeding Abstracts, Vol. 62, 1992, pp. 823-831.

[32] D. L.Jennings and C. Iglesias, "Breeding for Crop Improvement," In: R. J. Hillocks, J. M. Thresh and A. C. Bellotti, Eds., Cassava: Biology, Production and Utilization, CABI Publishing, New York, 2002, pp. 149-166. doi: 10.1079/9780851995243.0149

[33] J. H. Cock and M. A. El-Sharkawy, "Physiological Characteristics for Cassava Selection," Experimental Agriculture, Vol. 24, 1988, pp. 443-448.

[34] J. H.Cock and M. A. El-Sharkawy, "The Physiological Response of Cassava to Stress," Proceedings 7th Symposium of the International Society of Tropical Root and Tuber Crops, Gosier (Guadeloupe), 1-6 July 1985, Institute National de la Recherche Agronomique (INRA), Paris, 1988, pp. 451-462.

[35] M. A. El-Sharkawy, "Cassava Biology and Physiology," Plant Molecular Biology, Vol. 56, No. 4, 2004, pp. 481501. doi:10.1007/s11103-005-2270-7

[36] P. Pingali, "Prepared Remarks Presented at the World Food Prize Symposium," Bill \& Melinda Gates Foundation, Seattle, 2010.

http://www.gatesfoundation.org/speeches-commentary/Pa ges/prabhu-pingali-2010-world-food-prize-symposium.as $\mathrm{px}$

[37] M. A. El-Sharkawy, J. H. Cock, J. K. Lynam, A. D. P. Hernández and L. F. Cadavid, "Relationships between
Biomass, Root-Yield and Single-Leaf Photosynthesis in Field-Grown Cassava," Field Crops Research, Vol. 25, No. 3-4, 1990, pp. 183-201. doi:10.1016/0378-4290(90)90002-S

[38] T. Ramanujam, "Effect of Moisture Stress on Photosynthesis and Productivity of Cassava," Photosynthetica, Vol. 24, No. 2, 1990, pp. 217-224.

[39] J. B. O. Ogola and C. Mathews, "Adaptation of Cassava (Manihot esculenta) to the Dry Environments of Limpopo, South Africa: Growth, Yield and Yield Components," African Journal of Agricultural Research, Vol. 6, No. 28, 2011, pp. 6082-6088.

[40] M. A. El-Sharkawy, S. M. de Tafur and L. F. Cadavid, "Potential Photosynthesis of Cassava as Affected by Growth Conditions," Crop Science, Vol. 32, No. 6, 1992, pp. 1336-1342. doi:10.2135/cropsci1992.0011183X003200060006x

[41] M. A. El-Sharkawy and J. D. Hesketh, "Photosynthesis among Species in Relation to Characteristics of Leaf Anatomy and $\mathrm{CO}_{2}$ Diffusion Resistances," Crop Science, Vol. 5, 1965, pp. 517-521. doi:10.2135/cropsci1965.0011183X000500060010x

[42] M. A. El-Sharkawy, "International Research on Cassava Photosynthesis, Productivity, Eco-Physiology, and Responses to Environmental Stresses in the Tropics," Photosynthetica, Vol. 44, No. 4, 2006, pp. 481-512. doi:10.1007/s11099-006-0063-0

[43] M. A. El-Sharkawy, Y. López and L. M. Bernal, "Genotypic Variations in Activities of Phosphoenolpyruvate Carboxylase (PEPC) and Correlations with Leaf Photosynthetic Characteristics and Crop Productivity of Cassava Grown in Lowland Seasonally Dry Tropics," Photosynthetica, Vol. 46, No. 2, 2008, pp. 238-247. doi:10.1007/s11099-008-0038-4

[44] CIAT, "Cassava Program Annual Report for 1993," Centro Internacional de Agricultura Tropical, Cali, Colombia, 1993.

[45] A. Jarvis, J. Ramirez-Villegas, B. V. H. Campo and C. Navarro-Racines, "Is Cassava the Answer to African Climate Change Adaptation," Tropical Plant Biology, Vol. 5, No. 1, 2012, pp. 9-29. doi:10.1007/s12042-012-9096-7

[46] D. M. Rosenthal and D. R. Ort, "Examining Cassava's Potential to Enhance Food Security under Climate Change," Tropical Plant Biology, Vol. 5, No. 1, 2012, pp. 30-38. doi:10.1007/s12042-011-9086-1

[47] M. D. Fernández, M. D. W. Tezara, E. Rengifo and A. Herrera, "Lack of Down Regulation of Photosynthesis in a Tropical Root Crop, Cassava, Grown under Elevated $\mathrm{CO}_{2}$ Concentration," Functional Plant Biology, Vol. 29, No. 7, 2002, pp. 805-814. doi:10.1071/PP01165

[48] L. H. Ziska, K. P. Hogan, A. P. Smith and B. G. Drake, "Growth and Photosynthesis Response of Nine Tropical Species with Long-Term Exposure to Elevated Carbon Dioxide," Oecologia, Vol. 86, No. 3, 1991, pp. 383-389. doi:10.1007/BF00317605

[49] R. M. Gleadow, J. R. Evans, S. McCaffery and T. R. Cavagnaro, "Growth and Nutritive Value of Cassava 
(Manihot esculenta Crantz) are Reduced When Grown in Elevated $\mathrm{CO}_{2}$," Plant Biology, Vol. 11, No. S1, 2009, pp. 76-82. doi:10.1111/j.1438-8677.2009.00238.x

[50] D. Pellet and M. A. El-Sharkawy, "Cassava Varietal Response to Phosphorus Fertilization. I. Yield, Biomass and Gas Exchange," Field Crops Research, Vol. 35, No. 1, 1993, pp. 1-11. doi:10.1016/0378-4290(93)90131-6

[51] H. J. Veltkamp, "Physiological Causes of Yield Variation in Cassava," Ph.D. Thesis, Wageningen Agricultural University, Wageningen, The Netherlands, 1985.

[52] S. L. Tan and J. H. Cock, "Branching Habit as a Yield Determinant in Cassava," Field Crops Research, Vol. 2, 1979, pp. 281-289. doi:10.1016/0378-4290(79)90029-7

[53] M. A. El-Sharkawy, "How Can Calibrated ResearchBased Models be Improved for Use as a Tool in Identifying Genes Controlling Crop Tolerance to Environmental Stresses in the Era of Genomics-From an Experimentalist's Perspective," Photosynthetica, Vol. 43, No. 2, 2005, pp. 161-176. doi:10.1007/s11099-005-0030-1

[54] M. A. El-Sharkawy, "Cassava: Physiological Mechanisms and Plant Traits Underlying Tolerance to Prolonged Drought and Their Application for Breeding Cultivars in The Seasonally Dry and Semiarid Tropics," In: F. M. da Matta, Ed., Ecophysiology of Tropical Tree Crops, Nova Science Publishers, Hauppauge, New York, 2010, pp. 71-110.

[55] R. Sangpenchan, "Climate Change Impacts on Cassava Production in Northeast Thailand," Msc Thesis, The Pennsylvania State University, University Park, 2009. https://etda.libraries.psu.edu/paper/9952/5435

[56] M. A. El-Sharkawy and J. H. Cock, "Water Use Efficiency of Cassava, I: Effects of Air Humidity and Water Stress on Stomatal Conductance and Gas Exchange," Crop Science, Vol. 24, No. 3, 1984, pp. 497-502. doi:10.2135/cropsci1984.0011183X002400030017x

[57] J. H. Cock, M. C. M. Porto and M. A. El-Sharkawy, "Water Use Efficiency of Cassava, III: Influence of Air Humidity and Water Stress on Gas Exchange of Field Grown Cassava," Crop Science, Vol. 25, No. 2, 1985, pp. 265-272. doi:10.2135/cropsci1985.0011183X002500020015x

[58] M. A. El-Sharkawy and J. H. Cock, "The Humidity Factor in Stomatal Control and Its Effect on Crop Productivity," In: R. Marcelle, H. Clijsters and M. Van Poucke, Eds., Biological Control of Photosynthesis, Martinus Nijhoff Publishers, Dordrecht, Netherlands, 1986, pp. 187198. doi:10.1007/978-94-009-4384-1_17

[59] M. A. El-Sharkawy and L. F. Cadavid, "Response of Cassava to Prolonged Water Stress Imposed at Different Stages of Growth," Experimental Agriculture, Vol. 38, No. 3, 2002, pp. 333-350. doi:10.1017/S001447970200306X

[60] M. A. El-Sharkawy and S. M. de Tafur, "Comparative Photosynthesis, Growth, Productivity, and Nutrient Use Efficiency among Tall- and Short-Stemmed Rain-Fed Cassava Cultivars," Photosynthetica, Vol. 48, No. 2, 2010, pp.173-188. doi:10.1007/s11099-010-0023-6

[61] G. Byju and M. H. Anand, "Differential Response of Short-and Long-Duration Cassava Cultivars to Applied
Mineral Nitrogen," Journal of Plant Nutrition and Soil Science, Vol. 172, 2009, pp. 572-575. doi:10.1002/jpln.200800044

[62] C. A. de Vries, J. D. Ferwerda and M. Flach, "Choice of Food Crop in Relation to Actual and Potential Production in the Tropics," Netherlands Journal of Agricultural Science, Vol. 19, 1967, pp. 241-248.

[63] T. L. T. Hguyen, S. H. Gheewala and S. Garivait, "Full Chain Energy Analysis of Fuel Ethanol from Cassava in Thailand," Environmental Science Technology, Vol. 41, No. 11, 2007, pp. 4135-442. doi:10.1021/es0620641

[64] W. Wang, "Cassava Production for Industrial Utilization in China-Present andFuture Perspective," In: Cassava Research and Development in Asia: Exploring New Opportunities for an Ancient Crop, Seventh Regional Cassava Workshop, Bangkok, Thailand, 28 October-1 November 2002, pp. 33-38.

[65] C. Jansson, A. Westerbergh, J. Zhang, X. Hud and C. Sun, "Cassava, a Potential Biofuel Crop in China," Applied Energy, Vol. 86, 2009, pp. S95-S99. doi:10.1016/j.apenergy.2009.05.011

[66] D. Hillel and C. Rosenzweig, Eds., "Handbook of Climate Change and Agroecosystems: Impacts, Adaptation, and Mitigation," Imperial College Press, London, 2011.

[67] IPCC, "Fourth Assessment Report: Climate Change 2007 (AR4), Cambridge, UK and New York, 2007.

[68] M. B. Kirkham, "Elevated Carbon Dioxide: Impacts on Soil and Plant Water Relations," CRC Press, Boca Raton, 2011. doi: $10.1201 / \mathrm{b} 10812$

[69] M. A. El-Sharkawy, J. H. Cock and A. A. K. Held, "Water Use Efficiency of Cassava. II. Differing Sensitivity of Stomata to Air Humidity in Cassava and Other WarmClimate Species," Crop Science, Vol. 24, No. 3, 1984, pp. 503-507. doi:10.2135/cropsci1984.0011183X002400030018x

[70] R. H. Howeler, "Long-Term Effect of Cassava Cultivation on Soil Productivity," Field Crops Research, Vol. 26, 1991, pp. 1-18. doi:10.1016/0378-4290(91)90053-X

[71] R. H. Howeler, "Cassava Mineral Nutrition and Fertilization,” In: R. J. Hillocks, J. M. Thresh and A. C. Bellotti, Eds., Cassava: Biology, Production and Utilization, CABI Publishing, New York, 2002, pp. 115-147. doi:10.1079/9780851995243.0115

[72] D. Pellet and M. A. El-Sharkawy, "Cassava Varietal Response to Phosphorus Fertilization, II: Phosphorus Uptake and Use Efficiency," Field Crops Research, Vol. 35, No. 1, 1993, pp. 13-20. doi:10.1016/0378-4290(93)90132-7

[73] CIAT, "Cassava Program Annual Report for 1994," Centro Internacional de Agricultura Tropical, Cali, Colombia, 1994.

[74] CIAT, "Cassava Program Annual Report for 1987-1991," Centro Internacional de Agricultura Tropical, Cali, Colombia, 1991.

[75] CIAT, "Cassava Program Annual Report for 1992," Centro Internacional de Agricultura Tropical, Cali, Colombia, 1992.

[76] S. M. de Tafur, M. A. El-Sharkawy and L. F. Cadavid, 
"Response of Cassava (Manihot esculenta Crantz) to Water Stress and Fertilization," Photosynthetica, Vol. 34, No. 2, 1997, pp. 233-239. doi:10.1023/A:1006892607834

[77] C. Iglesias, M. Bonierbale, M. El-Sharkawy, L. Lozano, A. Bellotti and C. Wheatley, "Focusing Basic Research for Cassava Varietal Improvement," In: R. H. Howeler, Ed., Cassava Breeding, Agronomy Research and Technology Transfer in Asia, Centro International de Agricultura Tropical (CIAT), Cali, Colombia, 1995, pp. 40-60.

[78] CIAT, "Cassava Program Annual Report for 1990," Centro Internacional de Agricultura Tropical, Cali, Colombia, 1990.

[79] M. A. El-Sharkawyand L. F. Cadavid, "Genetic Variation within Cassava Germplasm in Response to Potassium," Experimental Agriculture, Vol. 36, No. 3, 2000, pp. 323334. doi:10.1017/S0014479700003045

[80] CIAT, "Cassava Program Annual Report for 1995," Centro Internacional de Agricultura Tropical, Cali, Colombia, 1995.

[81] D. Pellet and M. A. El-Sharkawy, "Sink-Source Relations in Cassava: Effects of Reciprocal Grafting on Yield and Leaf Photosynthesis," Experimental Agriculture, Vol. 30, No. 3, 1994, pp. 359-367. doi:10.1017/S0014479700024479

[82] R. H. Howeler, "Potassium Nutrition of Cassava," In: R. D. Munson, Ed., Potassium in Agriculture, American Society of Agronomy, Madison, Wisconsin, 1985, pp. 819841.

[83] G. O. Obigbesan, "Investigations on Nigerian Root and Tuber Crops: Response of Cassava Cultivars to Potassium Fertilizer in Western Nigeria," Journal of Agricultural Science, Vol. 89, No. 1, 1977, pp. 23-27. doi:10.1017/S0021859600027155

[84] G. O. Obigbesan, "Investigations on Nigerian Root and Tuber Crops: Effect of Potassium on Starch Yields, HCN, Content and Nutrient Uptake of Cassava (Manihot esculenta)," Journal of Agricultural Science, Vol. 89, No. 1, 1977, pp. 29-34. doi:10.1017/S0021859600027167

[85] B. M. Kumar, P. G. Nair and K. R. Lakshmi, "Inter-Relationships of Potassium, Calcium and Magnesium of Cassava in an Ultisol," Journal of Root Crops, Vol. 17, 1991, pp. 77-82.

[86] K. C. M. Thampatti and P. Padmaja, "Effect of UreaNeem Cake Blend on N and K Nutrition of Cassava," Journal of Root Crops, Vol. 21, 1995, pp. 39-42.

[87] D. Pellet and M. A. El-Sharkawy, "Cassava Varietal Response to Fertilization: Growth Dynamic and Implications for Cropping Sustainability," Experimental Agriculture, Vol. 33, 1997, pp. 353-365. doi:10.1017/S0014479797003013

[88] E. J. Burke, S. J. Brown and N. Christidis, "Modeling the Recent Evolution of Global Drought and Projections for the Twenty-First Century with the Hadley Centre Climate Model," Journal of Hydrometeorology, Vol. 7, No. 5, 2006, pp. 1113-1125. doi:10.1175/JHM544.1

[89] J. Gornall, et al., "Implications of Climate Change for Agricultural Productivity in The Early Twenty-First Cen- tury," Philosophical Transactions of the Royal Society B-Biological Sciences, Vol. 365, 2010, pp. 2973-2989. doi:10.1098/rstb.2010.0158

[90] K. Strzepek and B. Boehlert, "Competition for Water for the Food System," Philosophical Transactions of the Royal Society B-Biological Sciences, Vol. 365, 2010, pp. 2927-2940. doi:10.1098/rstb.2010.0152

[91] A. Sasson, "Feeding Tomorrow's World," United Nations Educational, Scientific and Cultural Organization (UNESCO)/CTA, Paris, 1990.

[92] C. Rosenzweig and M. L. Parry, "Potential Impact of Climate Change on World Food Supply," Nature, Vol. 367, No. 13, 1994, pp. 133-138. doi:10.1038/367133a0

[93] M. L. Parry, C. Rosenzweig, A. Iglesias, M. Livermore and G. Fischer, "Effects of Climate Change on Global Food Production under SRES Emissions and Socioeconomic Scenarios," Global Environmental Change, Vol. 14, No. 1, 2004, pp. 53-67. doi:10.1016/j.gloenvcha.2003.10.008

[94] S. Romanoff and J. Lynam, "Cassava and African Food Security: Some Ethnographic Examples," Ecology of Food Nutrition, Vol. 27, 1992, pp. 29-41. doi:10.1080/03670244.1992.9991223

[95] W. Kamukondiwa, "Alternative Food Crops to Adapt to Potential Climatic Change in Southern Africa," Climate Research, Vol. 6, 1996, pp. 153-155. doi: $10.3354 / \mathrm{cr} 006153$

[96] FAO, "Adaptation to Climate Change in Agriculture, Forestry and Fisheries: Perspective, Framework and Priorities," FAO Inter-Departmental Working Group on Climate Change, Food and Agriculture Organization of the United Nations (FAO), Rome, 2007. http://www.fao.org/climatechange/en/

[97] S. M. de Tafur, M. A. El-Sharkawy and F. Calle, "Photosynthesis and Yield Performance of Cassava in Seasonally Dry and Semiarid Environments," Photosynthetica, Vol. 33, No. 2, 1997, pp. 249-257. doi:10.1023/A:1022116414969

[98] CNPMF/EPAGRI/CIAT, "Project for the Development of Cassava Germplasm for Drier Tropicsand Subtropical Agro-Ecosystems: Annual Report 1991-1992, Work Plan 1992-1993," Centro Nacional de Pesquisa de Mandioca e Fruticultura Tropical (CNPMF), Empresa de Pesquisa Agropecuaria e Difusão de Tecnologia de Santa Catarina (EPAGRI), and Centro Internacional de Agricultura Tropical (CIAT), Cruz das Almas, Brazil, 1991-1992, p. 51.

[99] W. M. G.Fukuda, M. Ender and C. Iglesias, "Project for the Development of Cassava Germplasm for Drier Tropics and Subtropical Agro-Ecosystems: Annual Report 1992-1993, Work Plan 1993-1994," CNPMF, EPAGRI, CIAT, Cruz das Almas, Brazil, 1992-1993, p. 55.

[100] W. M. G. Fukuda and N. Saad, "Participatory Research in Cassava Breeding with Farmers in Northeastern Brazil: Annual Report, May 2001," EMBRAPA/CNPMF, Brazil, and PRGA Program, CIAT, Colombia, 2001, p. 39.

[101] N. Saad, N. Lilja and W. M. G. Fukuda, "Participatory Cassava Breeding in Northeast Brazil: Who Adopts and 
Why? Working Document No. 24," PRGA/FUTURE HARVEST/CGIAR. CIAT, Cali, Colombia, 2005, p. 28.

[102] S. P. Long, E. A. Ainsworth, A. D. B. Leakey, J. Nösberger and D. R. Ort, "Food for Thought: Lower-than-Expected Crop Yield Stimulations with Rising $\mathrm{CO}_{2}$ Concentrations," Science, Vol. 312, No. 5782, 2006, pp. 19181921. doi:10.1126/science. 1114722

[103] M. Erbs, R. Manderscheid and H.-J. Weigel, "A Combined Rain Shelter and Free-Air $\mathrm{CO}_{2}$ Enrichment System to Study Climate Change Impacts on Plants in the Field," Methods in Ecology and Evolution, Vol. 3, No. 1, 2012, pp. 81-88. doi:10.1111/j.2041-210X.2011.00143.x

[104] B. A. Kimball, "Lessons from FACE: $\mathrm{CO}_{2}$ Effects and Interactions with Water, Nitrogen and Temperature," In: D. Hillel and C. Rosenzweig, Eds., Handbook of Climate Change and Agroecosystems: Impacts, Adaptation, and Mitigation, Imperial College Press, London, 2011, pp. 87-107.

[105] T. L. Setter and M. A. Fregene, "Recent Advances in Molecular Breeding of Cassava For Improved Drought Stress Tolerance," In: M. A. Jenks, P. M. Hasegawa and S. M. Jain, Eds., Advances in Molecular Breeding toward
Drought and Salt Tolerant Crops, Springer, 2007, pp. 701-7011. doi:10.1007/978-1-4020-5578-2 28

[106] P. Zhang, et al., "Senescence-Inducible Expression of Isopentenyl Transferase Extends Leaf Life, Increases Drought Stress Resistance and Alters Cytokinin Metabolism in Cassava," Journal of Integrative Plant Biology (JIPB), Vol. 52, No. 7, 2010, pp. 653-669. http://www.jipb.net/1291369783750000.pdf

[107] N. Taylor, P. Chavarriaga, K. Raemakers, D. Siritunga and P. Zhang, "Development and Application of Transgenic Technologies in Cassava," Plant Molecular Biology, Vol. 56, No. 4, 2004, pp. 671-688. doi:10.1007/s11103-004-4872-X

[108] M. A. El-Sharkawy, "Utility of Basic Research in Plant/ Crop Physiology in Relation to Crop Improvement: A Review and a Personal Account," Brazilian Journal of Plant Physiology, Vol. 18, No. 4, 2006, pp. 419-446. doi:10.1590/S1677-04202006000400001

[109] D. J. Connor, R. S. Loomis and K. G. Cassman, “Crop Ecology: Productivity and Management in Agricultural Systems," 2nd Edition, Cambridge University Press, Cambridge, 2011. doi:10.1017/CBO9780511974199 